JULIANA ARID

\title{
EFEITO DA RADIOTERAPIA NA AdESÃO E INTERFACE AO Substrato de Dentes Permanentes.
}

Dissertação apresentada à Faculdade de Odontologia de Ribeirão Preto da Universidade de São Paulo para obtenção do Título de Mestre em Ciências junto ao Programa de Odontopediatria com Área de Concentração em Odontopediatria.

Orientada: Juliana Arid

Orientadora: Profa. Dra. Alexandra Mussolino de Queiroz 


\section{AUTORIZAÇÃO PARA REPRODUÇÃO}

Autorizo para reprodução e divulgação total ou parcial deste trabalho por qualquer meio convencional ou eletrônico, para fins de estudo e pesquisa, desde que citada a fonte.

\section{Ficha CATALOgRÁfica}

Arid, Juliana

Efeito da radioterapia na adesão e interface ao substrato de dentes permanentes. Ribeirão Preto, 2015.

98p. : il. ; $30 \mathrm{~cm}$

Dissertação de Mestrado apresentada à Faculdade de Odontologia de Ribeirão Preto/USP - Área de concentração: Odontopediatria.

Orientadora: Queiroz, Alexandra Mussolino

1. Radioterapia. 2. Neoplasias de cabeça e pescoço. 3. Esmalte dentário. 4. Dentina. 5. Sistemas adesivos. 6. Resistência ao cisalhamento. 
Arid,J. Efeito da radioterapia na adesão e interface ao substrato de dentes permanentes.

Dissertação apresentada à Faculdade de Odontologia de Ribeirão Preto da Universidade de São Paulo, para obtenção do Título de Mestre em Ciências

Área de Concentração: Odontopediatria

Data da defesa:

\section{BANCA EXAMINADORA}

Prof. Dr.

Instituição:

Julgamento:

Assinatura:

Prof. Dr.

Instituição:

Julgamento:

Assinatura:

Prof. Dr.

Instituição:

Julgamento:

Assinatura: 



\section{DADOS CURRICULARES}

\section{JULIANA ARID}

Nascimento 28 de Abril de 1990 - São José do Rio Preto, São Paulo

Filiação João José Arid Filho

Ana Maria da Silva Arid

2009 - 2012 Curso de Graduação em Odontologia

Faculdade de Odontologia de Ribeirão Preto - USP

2013-2014 Curso de Aperfeiçoamento no Atendimento Odontológico a Pacientes Especiais

Faculdade de Odontologia de Ribeirão Preto - USP

2013 - 2015 Curso de Especialização em Odontopediatria Associação Odontológica de Ribeirão Preto

2013 - 2015 Curso de Pós-Graduação (Mestrado) em Odontologia Área de concentração: Odontopediatria Faculdade de Odontologia de Ribeirão Preto - USP 

"Suba o primeiro degrau com fé. Não é necessário que você veja toda a escada. Apenas dêe primeiro passo." 



\section{Dedicatória}

Às duas pessoas mais especiais e que eu mais amo na vida, meus pais Ana Xaria da Silva Arid e João José Arid Fillho. Eu posso até tentar por em palauras meus sentimentos e minha gratidão a vocês, mas tudo o que eu escrever aqui jamais chegará perto do amor e orgulho que tenho por vocês. Simplesmente obrigada por tudo!!!! Tudo que eu tenho, aonde eu cheguei, o que eu aprendi e o que sou en devo a vocês, devo ao amor e dedicação imensuráveis que vocês têm por mim. Obrigada por todas às vezes que vocês abriram mão de vocês' mesmos por mim, obrigada pelo carinho, pelo amor, pela amizade, pela educação que vocês me deram e por todas as oportunidades que me proporcionaram. Sem vocês eu nada seria, nada teria e nada faria sentido, sem o amor e companheirismo de vocês nada disso teria sido possivel. Vocês são exemplos de pessoas, pais e de casal, e eu tenho muito orgulho de vocês e quero que vocêss tenham muito orgulho de mim, pois é assim que posso retribuir a vida que vocês dedicaram a mim. Eu amo vocês acima de tudo e de todos, vocêss são minha base, meu porto seguro, meu tudo. Eu só tenho a agradecer a Deus pela familia que Ele me deu, pois melhor e mais cheia de amor seria impossivel. Obrigada por acreditarem e confiarem em mim. Vocês são tudo pra mim!!! Almo vocês além da vida!!!

Zlos meus padrinhos Elaine Aparecida Vetorasso e Antônio Vetorasso (in memorian) que nunca mediram esforços para ajudarem a minha família. Duas pessoas que eu tenho imenso amor $e$ gratidão. Não sei medir em palauras meu sentimento por pessoas tão especiais. Obrigada Xadrinha e Dadrinho por tudo que vocês já fizeram por mim, as lembranças dos bons momentos se fazem presentes diariamente no meu coração. Xadrinha, obrigada por sempre estar presente na minha vida, por me apoiar, me dar forças, por acreditar e confiar em mim. Dadrinho sei que do céu o senhor está torcendo e othando por mim, sinto muito a falta do senhor, obrigada por tudo. Serei eternamente grata por tudo. Almo muito vocês!!! 
Zlo meu avô, João José Arid, que em vida torceu e acreditou tanto em mim. Vồ o senhor sempre se fez tão presente na minha vida, torcendo por minhas vitórias, acreditando em mim mais do que ninguém. Queria tanto que o senhor estivesse aqui comigo neste momento tão importante, mas sei que daí de cima o senhor está torcendo e othando por mim. Tenho muito orgulho de ser sua neta e sinto sua falta todos os dias. Saudades eternas! 


\section{Zlgradecimentos Especiais}

À Profa. Dra. Alexandra Xussolino de Queiroz que me recebeu tão bem na sua sala em 2010, que en não sai de lá até hoje. Danda, vocêe é muito mais do que uma professoralorientadora e uma amiga, é como uma mãe pra mim aqui em Ribeirão. E você exerce muito bem essa funçãa de mãe, sempre cuidado e defendendo seus filhos, e comigo não foi diferente. Não tenho palauras para te agradecer pelo excelente convivio ao longo de todos esses anos, por todas as vezes que você me apoiou, tomou min has dores, me defendeu, me ajudou, me escutou e me fez vir. Obrigada por todas as oportunidades que você já me deu e que ainda me dá, por acreditar tanto em mim, sempre me colocar pra frente, por todos conselhos (acadêmicos e pessoais) e ensinamentos e por tantos momentos bons que eu sempre vou levar no meu coração.

Eu vejo tanta gente com "medo", "receio" do seu orientador e não consigo imaginar como seja isso, pois otho para nossa relação que sempre tão boa, cheia de carinho, cumplicidade e sinceridade. Você sempre tão carinhosa pegou na minha mão quando eu ainda estava no segundo ano da graduação e me ensinou tanta coisa, me fez crescer não só profissionalmente, mas também como pessoa, porque você é um exemplo de pessoa boa, educada, gentil e amorosa. Danda, você é aquela pessoa que eu falo: "Quando eu "crescer" quero ser igual a ela!".

Ao longo destes cinco anos muita coisa mudou, muita gente entrou e saiu de nossas vidas, muitas coisas boas e também ruins aconteceram, nosso visual mudou (porque você também é um exemplo de beleza, quando en penso em ir "maloqueira" à faculdade lembro que vou passar o dia ao seu lado e já me arrumo] e até muitos alimentos foram cortados de nossos cardápios, meu sentimento por você também mudou, pois ele cresce a cada dia, assim como minha admiração por você.

Danda, obrigada por tudo!!!!! Sempre serei grata a você e levarei nossos momentos não só na minha memória, mas no meu coraçãa. Você é um exemplo de pessoa pra mim. Obrigada por ser essa mãe que a faculdade me deu! 
À Profa. Dra. Regina Guenka Dalma-Dibb que foi um presente que o mestrado me deu. Uma "fada madrinha" que fez tudo o que estava no papel virar realidade. Não é a toa que sua sala vive lotada não é professora? Como não se encantar com a senhora? Como não dar uma passadinha lá, seja para usar o confocal, fazer estatistica, dar um Bom Dia e bater um papo.

A senhora é um exemplo de profissional, pessoa e mãe. Se eu pudesse pegar um pouquinho de todas suas qualidades já estaria bem satisfeita. Como pode uma pessoa saber tanto? Não só na teoria, mas na prática também. E como pode ter tanta paciência para ajudar os alunos, muitas vezes perdidos (como eu), que chegam à sua sala pedindo ajuda?

Obrigada por me ajudar tanto, por fazer mesmo o que parecia impossivel ficar tão simples e claro. Obrigada também pelos conselhos, pelas conversas, por todo aprendizado que a senhora passa não só a mim, mas a todos seus alunos, e passa todo esse conhecimento de uma forma tão simples e natural, tornando tudo mais claro. Só tenho a agradecer à senhora por ter me acolhido, por todas as vezes que me ajudou e por ser essa pessoa sempre tão bem humorada, sorridente, feliz e bem disposta. Nada disso teria acontecido sem sua ajuda Professora, e eu só tenho a te agradecer por tudo o que a senhora fez por mim. Serei sempre grata por todo carinho e atenção que a senhora teve comigo. Obrigada por tudo, tudo mesmo!!!!! 


\section{Agradecimentos}

À Universidade de São Paulo, na pessoa do atual reitor, Prof. Dr. Xarco Zntonio Zago, e do vicereitor, Prof. Dr. Vahan Zgopyan.

À Faculdade de Odontologia de Ribeirão Preto da Universidade de São Paulo, na pessoa do atual diretor, Drof. Dr. Valdemar Mallet da Rocha Barros, e da vice-diretora, Profa. Dra. Léa Assed Bezerra da Silva.

Z) Coordenação do Curso de Pós Graduação em Odontopediatria da Faculdade de Odontologia de Ribeirão Preto da Universidade de São Daulo, na pessoa da coordenadora, Profa. Dra. Raquel Zssed Bezerra Segato e da suplente da coordenação Profa. Dra. Léa Zlssed Bezerra da Silua.

Ż CAPES, pela bolsa concedida.

Alo Professor Dr. Harley Francisco de Oliveira do Departamento de Clinica Médica, da Faculdade de Medicina de Ribeirão Preto da Universidade de São Paulo, por nos dar a oportunidade de realizar esta pesquisa no Serviço de Radioterapia do Hospital das Clinicas e nos acolher de maneira tão gentil, sempre muito solicito e educado deixando nos muito a vontade e tornando o aprendizado muito mais fácil e agradável.

Ż Profa. Dra. Léa Assed Bezerra da Silva pela confiança, por todas as oportunidades proporcionadas e pela grande pessoa e profissional que senhora é. Obrigada por ter me recebido tão bem na Odontopediatria.

Zlo Prof. Dr. Paulo Nelson Filho que mais que um grande professor é um exemplo de pessoa e profissional dedicado. Se um dia eu for um pouquinho do que o senhor é já me darei por satisfeita. Obrigada por ter me ajudado desde a época da Graduação, sempre confiando em mim, me mostrando que eu sou capaz e me dando oportunidades de crescer profissionalmente. Xeus sinceros agradecimentos a este profissional no qual me espelho tanto. 
Às Profa. Dra. Andiara de Rossi Daldegan e Profa. Dra. Raquel Assed Bezerra Segato, pelos momentos agradáveis que passei com vocês, por todo aprendizado, pela paciência de me ensinar e me motivar. Exemplo de profissionais que tenho o prazer e o privilégio de poder conviver diariamente. Obrigada pelas conversas, consethos, incentivos e por sempre estarem disponiveis para me apoiarem e me ajudarem.

Alo Prof. Dr. Fabricio Kitazono de Carvalho (Faforp) que mais que um professor é um amigo. Faforp, não tenho palauras para agradecer toda cofiança que você tem em mim, por me ajudar tanto em todos os momentos que eu precisei desde a graduação, por dividir sua mesa comigo e por todas as oportunidades de crescer profissionalmente que você me proporcionou. Serei sempre grata a você. Obrigada por tudo o que já fez e faz por mim.

Alos demais professores do Departamentro de Clinica Infantil Profa. Dra. Aldevina Campos de Freitas, Prof. Dr. Fábio Lourenço Romano, Prof. Dr. José Tarcisio Lima Ferreira, Profa Dra. Kranya Victoria Diaz Serrano, Profa. Dra. Xaria Bernadete Sasso, Profa. Dra. Xaria Cristina Borsatto, Profa Profa. Dra. Xaria da Conceição Pereira Saraiva e Profa. Dra. Xirian Aliko Nakane Matsumoto por todos os ensinamentos ao longo destes anos, pela convivência sempre gentil e agradável. Cada um com seu jeito único deixou uma marca de ensinamento em mim. Obrigada por todas as oportunidades, ajudas, consethos e pelo aprendizado passado por vocêss.

Alos Funcionarios do Departamento de Clinica Infantil: Carolina Paes Torres Mantouani, Fátima Aparecida Jacinto Daniel, Filomena Leli Placciti, Francisco Wanderley Garcia de Paula e Silva, Xarco Antônio dos Santos, Xatheus Xorelli Zanela, que sempre me trataram tão bem, sempre dispostos a ajudar. Obrigada pelo ótimo convivio todos estes anos, pelas risadas e pelo apoio.

Ż Dra. Xarifia Pacifico Lucisano, que desde a graduação me ajudou e me apoiou, Xá obrigada por ter pegado na minha mão e muito ter me ensinado, com esse jeitinho delicado você encanta a todos ao seu redor; á Micheli Cristina Leite Rovanholo que toma conta de todos pós-graduandos do departamento, Xi obrigada por 
ser essa "mãezona" sempre disposta a ajudar, sempre me saluando e apoiando em todos meus sonhos, e á Nilza Leticia Xagalhäes que contagia qualquer lugar com sua alegria, obrigada por todas risadas, cantorias, histórias e almoços juntas. Com vocês o dia a dia na faculdade fica muito mais leve e prazeroso. Acima de tudo, obrigada pela amizade de vocês!

Zlos Funcionarios do Serviço de Radioterapia do Hospital das Clinicas, na pessoa do Rodrigo Travaini Favaro que com uma simpatia singular torna o ambiente da Radioterapia mais" "leve", levando alegria aqueles pacientes que estão passando por uma situação muito difícil e que tão bem me recebeu e muito me ensinou, não medindo esforços para dividir seu conhecimento.

Zlos Funcionarios do Departamento de Odontologia Restauradora que me receberam tão bem, em especial à Dra. Juliana Jandiroba Faraoni Romano que teve fundamental importância para o andamento $e$ conclusão deste projeto, sempre presente e disposta a ajudar, Iu obrigada por todas as vezes que você me ensinou, me ajudou e muitas vezes me acalmou fazendo com que eu "me sentisse em casa", è̀ Patrícia Xarchi que sempre se fez presente durante todo este projeto.

Zlos Funcionários da Seção de Pós-graduação da Faculdade de Odontologia de Ribeirão Preto da Universidade de São Paulo: Diego Fernando Perruco, Osabel Cristina Galino Sola e Mary Possani Carmessano pela atenção e por estarem sempre à disposição.

Ź todos alunos de Pós Graduação do Programa de Odontopediatria, muito obrigada pelos conhecimentos compartilhados, pelas risadas, conselhos, momentos de alegria, enfim por todos momentos bons que passamos juntos e que certamente levarei sempre comigo. Guardarei todos momentos comigo, todas risadas, e até mesmo todo stress. Ter vocês ao meu lado nesses anos foi muito bom, uma convivência muito agradável onde aprendi muita coisa. Cada uma de vocês é especial e conquistou um pedacinho do meu coração, espero que as amizades feitas aqui perdurem por muito tempo, pois vocêss são pessoas incriveis que eu tive a sorte de conhecer. 
Ź Carolina Xaschietto Pucinelli, por ser minha dupla, minha vizinha e acima de tudo minha amiga, obrigada pela convivência, pelo companheirismo, por todas confissões, conselhos, viagens e risadas; á Francine Lorencetti da Silva pela amizade, companheirismo, risadas, cantorias, almoços diários, Francis obrigada por todo apoio, pelas risadas e principalemente por sua amizade que é muito importante para mim; á Xariana de Oliveira Daltoé (Dalts), pelo companheirismo e cumplicidade, obrigada por ter se tornado uma amiga $e$ companheira de verdade, sempre me ajudando e apoiando e á Talitha de Siqueira Xellara que me ensinou tantas coisas, não só no mestrado mas também na vida, Tá obrigada por todo apoio, companheirismo e amizade ao decorrer destes anos. Vocês foram os methores presentes que o mestrado me deu! Zlmo vocês!

Al todos meus amigos que sempre torceram por mim, obrigada por estarem ao meu lado, mesmo que a distância, por me mandarem boas energias, por me apoiarem e dividirem comigo alegrias. Vocês's são muito importantes pra mim. Tenho um amor e carinho especial por cada um!!!

Ż Xinha Familia, que sempre torceu e acreditou em mim e mesmo de longe colaboraram muito para a realização deste sonho, pois sempre me apoiaram e acreditaram em mim. Em especial á Vó Zezé que sempre tão bem disposta contagia a todos com sua alegria de viver, se um dia eu for pelo menos um pouquinho do que a senhora é já ficarei feliz, obrigada por ser este exemplo de vida e motivaçãa, ao Vô Toninho e ás minhas primas irmãs Isabela e Xarcela as quais eu tenho como verdadeiras irmãs e que sempre estiveram ao meu lado para tudo o que eu precisei á vocês meu eterno amor e agradecimento.

Zi Deus, por ter me concedido a graça da vida, ter me dado uma familia maravilhosa e tantas oportunidades. Só tenho a agradecer ao Senhor por todas as benções e graças alcançadas.

E como já dizia Raul Seixas "Sonho que se sonha só é só um sonho que se sonha só. Xas sonho que se sonha junto é realidade", por isso quero agradecer a todos que de uma forma ou de outra me ajudaram para que este sonho se tornasse realidade. Obrigada!!!!! 
RESUMO

ABSTRACT

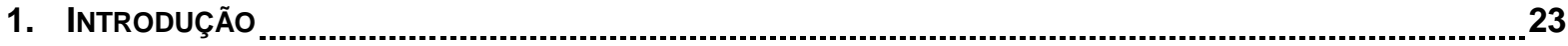

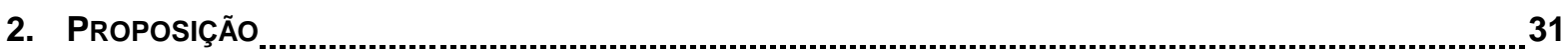

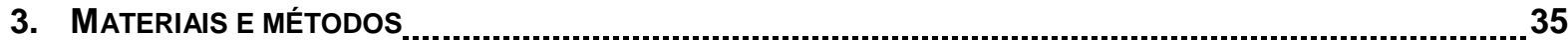

4. Resultados

5. DISCUSSÃO

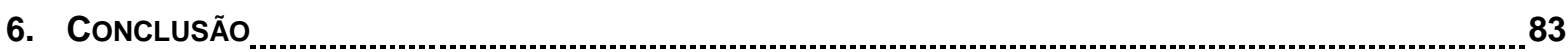

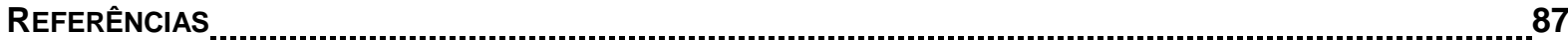

ANEXO 



\section{RESUMO}

Arid, J. Efeito da radioterapia na adesão e interface ao substrato de dentes permanentes. Ribeirão Preto, 2015. 98p. [Dissertação de mestrado]. Faculdade de Odontologia de Ribeirão Preto, São Paulo.

O câncer de cabeça e pescoço é, dentre todos os tipos de cânceres, o sétimo mais comum, dentre suas principais formas de tratamento está a radioterapia (RT), que é amplamente utilizada e eficiente, mas os efeitos colaterais aos tecidos adjacentes são inevitáveis. A realização do tratamento odontológico previamente a radioterapia é de suma importância e visa eliminar/reduzir os focos infecciosos presentes na cavidade bucal, sendo essencial a eliminação das lesões de cárie, e após a radioterapia é fundamental tratar as "cáries de radiação", que é um dos efeitos colaterais do tratamento radioterápico de cabeça e pescoço. Os sistemas resinosos são os materiais mais indicados para restauração dos dentes de pacientes submetidos à radioterapia, por isso o objetivo do presente estudo foi avaliar in vitro o efeito da radiação, no momento em que é realizada a restauração ao esmalte e a dentina, por meio de teste de cisalhamento, analisar longitudinalmente as alterações morfológicas na superfície do substrato dental durante a radiação por meio de microscopia confocal a laser e analisar qualitativamente a interface de união compósito/substrato dental por meio de microscopia eletrônica de varredura (MEV). Foram utilizados 60 terceiros molares permanentes, que foram seccionados em um total de 120 fragmentos de esmalte e 120 de dentina, e após o preparo da superfície foram divididos aleatoriamente em grupos 4 grupos ( $n=30)$ : $G 1$ (controle) - substrato sem irradiação + procedimento restaurador; $G 2$ procedimento restaurador realizado antes da RT; G3 - procedimento restaurador realizado após a RT; e G4 - procedimento restaurador realizado 6 meses após a RT. Cada um dos grupos foi dividido em 2 subgrupos, sendo empregado no subgrupo "A" (SGA) o adesivo Adper ${ }^{\mathrm{TM}}$ Single Bond 2 (SB); e no subgrupo "B" (SGB) o adesivo Clearfil SE Bond (CL), para o procedimento restaurador. Os espécimes foram irradiados com fração de dose de $2 \mathrm{~Gy}, 5$ dias consecutivos, até atingirem a dose total de 60Gy, com um total de 30 frações, durante 6 semanas. O procedimento restaurador foi realizado com resina Z350, e para padronização da restauração foi utilizada uma matriz, de forma que os espécimes apresentam $4 \mathrm{~mm}$ de altura e $2 \mathrm{~mm}$ de diâmetro. Os corpos de prova foram submetidos ao teste de resistência ao cisalhamento e depois analisou-se o modo de fratura. Foram selecionados 5 espécimes de cada substrato, para a realização da análise morfológica da superfície dental por meio da microscopia confocal, sendo estes avaliados a cada 10Gy. Para a análise da interface adesiva foram selecionados 3 espécimes de cada grupo e estes foram preparados para realização da MEV. O sistema adesivo CL apresentou desempenho superior, em ambos substratos, quando comparado o SB; quanto ao tempo da restauração, tanto em esmalte quanto em dentina, o grupo 2 apresentou os menores valores; o padrão de fratura predominante para todos os grupos foi a Adesiva; houveram alterações morfológicas notáveis em esmalte e dentina após a dose acumulativa de 30Gy, onde aos 60Gy, no esmalte, os prismas se tornaram amorfos e a camada interprismática degradada, e na dentina os túbulos dentinários encontravam-se completamente obliterados; na análise da interface adesiva do grupo 2 notou-se que quase não houve formação de tags e nos grupos 3 de esmalte a camada adesiva formada era mais fina, porém com formação de tags mais prolongados e na dentina houve formação de gaps.

Palavras-chave: Radioterapia; Neoplasias de cabeça de pescoço; Esmalte dentário; Dentina; Sistemas adesivos; Resistência ao cisalhamento 



\section{ABSTRACT}

Arid, J. Effect of radiotherapy on bonding and bonding interface to substrate of permanent teeth. Ribeirão Preto, 2015. 98p. [Dissertação de mestrado]. Faculdade de Odontologia de Ribeirão Preto, São Paulo.

Head and neck cancer is among all kinds of cancer the seventh most common and radiotherapy (RT) is one of its main treatments, which is widely used and efficient, but side effects are unavoidable. A dental treatment before RT is very important to reduce/eliminate infectious foci in the oral cavity, so it is essential to eliminate carious lesions, and after RT "radiation caries", which are a side effect of the treatment, must be eliminated. Adhesive systems are the most indicated to restore teeth of patients undergoing RT, so this study aimed to evaluate in vitro the effect of RT in the moment of the dental restorations in enamel and dentin, using shear bond strength tests, evaluate morphologic alterations at teeth surface during RT, with a laser confocal microscopy and to evaluate qualitatively the union interface of the composite/ dental substrate by scanning electron microscope (SEM). It was used 60 third molars, which were sectioned into 120 fragments of enamel and 120 of dentin, and after the surface prepare the specimens were randomly divided into 4 groups ( $n=30)$ : $G 1$ (control) - no irradiated substrate + restorative procedure; G2 - restorative procedure performed before RT; G3 - restorative procedure performed after RT; e G4 - restorative procedure performed 6 months after RT. Each group was divided into 2 subgroups: Subgroup "A" (SGA) in which was used the Adper ${ }^{\mathrm{TM}}$ Single Bond 2 (SB); and subgrup "B" in which was used Clearfil SE Bond (CL), for the restorative procedure. The specimens were fractionally irradiated by a dose of 2 Gy/day, 5 consecutive days, until it reached a total dose of $60 \mathrm{~Gy}$, in a total of 30 fractions, lasting 6 weeks. For the restorative treatment the resin Z350 was chosen, and for standardization it was used a matrix so all specimens had $4 \mathrm{~mm}$ height and $2 \mathrm{~mm}$ in diameter. The specimens were submitted to shear bond strength test and the fracture pattern was evaluated. It was chosen 5 specimens of each substrate for the morfological evaluation of the dental surface by a laser confocal microscopy, those were evaluate every 10Gy. To evaluate the adhesive interface it was chosen 3 specimens of each group and those were prepared for the SEM. A better performance was observed for the CL, in both dental substrates, rather than the SB; according to the period of restoration, in both enamel and dentin, Group 2 has showed lower values; the predominant fracture pattern to all groups was the Adesive one; there were morphological alterations in enamel and dentin after a cumulative dose of $30 \mathrm{~Gy}$, the prisms of enamel became formless and the interprismatic region was degraded after 60Gy, at the dentin the dental tubules were completely amorphous; the analysis of the interface adhesion has showed that in group 2 tags were barely formed, and in group 3 of enamel the adhesive layer was thinner, but tags were longer, and at the dentin gaps were observed.

Keywords: Radiotherapy; Head and Neck Neoplams; Dental Enamel; Dentin; Adhesive System; Shear Bond Strength 

1. Introdução 



\section{INTRODUÇÃO}

O termo "câncer de cabeça e pescoço" refere-se a neoplasias malignas localizadas no trato aerodigestivo, ou seja, cavidade bucal, faringe e laringe (Dobrossy, 2005; Ferlay et al., 2010; Gaudet et al., 2015), sendo o sétimo tipo de câncer mais comum (Rettig e D'souza, 2015). O seu tipo histológico mais frequente é o carcinoma de células escamosas (Lemaire et al., 2003; Lothaire et al., 2006; Rettig e D'souza, 2015), o qual compreende 90\% dos casos de câncer nessa região (Dobrossy, 2005). Nos Estados Unidos, a cada dia são diagnosticados 100 novos casos de câncer de cabeça e pescoço, e a cada hora uma pessoa vem a óbito (Overman, 2009). Este tipo de neoplasia acomete duas a três vezes mais homens do que mulheres (Dobrossy, 2005; Rettig e D'souza, 2015), segundo o Instituto Nacional de Câncer (INCA), o câncer na cavidade bucal é o quinto tipo mais comum em homens, com estimativa de 11.280 novos casos por ano para o Brasil (INCA). Em 2008 foi estimado que mais de 128.000 pessoas morreram devido ao câncer na cavidade bucal ao redor do mundo (Jemal et al., 2011).

Os agentes causais do câncer de cabeça e pescoço podem ser externos ou internos, ou seja, quando o indivíduo apresenta predisposição e ainda é exposto a agentes externos, que estão associados ao meio ambiente e hábitos, a chance de desenvolvimento das neoplasias é ainda maior. Nos casos de câncer de cabeça e pescoço os agentes externos estão relacionados principalmente ao consumo de álcool e tabaco (Kim, Hong e Khuri, 2002; Hashibe et al., 2009; Jemal et al., 2011; Zhou et al., 2013; Gaudet et al., 2015; Rettig e D'souza, 2015). O uso indiscriminado de bebidas alcoólicas, isolado de outros fatores, aumenta a chance de desenvolvimento de câncer na região de cabeça e pescoço em 1-4\% (Hashibe et al., 2007; Hashibe et al., 2009), especialmente na região hipofaringeal (Menvielle et al., 2004). O maior risco é quando há associação entre uso de álcool e de tabaco, pois estes apresentam efeito sinérgico (Blot et al., 1988; Hashibe et al., 2009; Jemal et al., 2011; Rettig e D'souza, 2015), sendo que para indivíduos que fumam dois maços de cigarro e bebem quatro doses de bebidas alcoólicas por dia o risco de desenvolvimento de câncer de cabeça e pescoço aumenta 35 vezes (Blot et al., 1988). Já foi demonstrado que 
90\% dos indivíduos que apresentam câncer de cabeça e pescoço fizeram uso de tabaco (Hashibe et al., 2007). Mesmo o tabaco que não é usado sob forma de cigarro, como por exemplo, indivíduos que mastigam tabaco, é nocivo e aumento o risco de aparecimento de câncer de cabeça e pesco (Secretan et al., 2009; Zhou et al., 2013), sendo estimado que seu uso aumente em até $80 \%$ o risco de aparecimento de câncer na cavidade bucal (Boffetta et al., 2008).

Desde a década passada a infecção pelo papiloma vírus humano (HPV), transmitido sexualmente, vem sendo reconhecida também como causa primária para o aparecimento do câncer de cabeça e pescoço, o que pode justificar o fato de pessoas mais jovens estarem apresentando câncer nesta região (Smith et al., 2004; Lothaire et al., 2006; Pintos et al., 2008; Jemal et al., 2011; Rettig e D'souza, 2015). A prevalência de câncer na região da orofaringe ocasionada pelo HPV vem aumentando, sendo atualmente estimada em $80 \%$ nos EUA (Gillison et al., 2008; Ang et al., 2010). Embora existam mais de 100 tipos de HPV apenas uma minoria é considerada de alto risco ou carcinogênica (Tota et al., 2011), e o HPV16 é responsável por mais de 90\% desta relação entre HPV e câncer de cabeça e pescoço (Herrero et al., 2003; Gillison et al., 2012).

Indivíduos diagnosticados com câncer de cabeça e pescoço podem ser tratados com cirurgia, radioterapia, quimioterapia ou pela combinação destes tratamentos (Kim, Hong e Khuri, 2002; Qing et al., 2015). A radioterapia é amplamente utilizada para o tratamento deste tipo de câncer, podendo ser indicada como terapia primária, coadjuvante ao tratamento cirúrgico e à quimioterapia ou como tratamento paliativo em estágios finais e inoperáveis da doença (Adelstein, 2003; Soares et al., 2011).

A radioterapia pode ser realizada com diferentes fontes de radiação ionizante, dentre elas a contatoterapia, roentgenterapia, unidade de cobalto, acelerador linear e isótopos radiotivos dependendo do tipo de lesão (superficial, semiprofunda ou profunda) (INCA). Essa terapia destrói os tecidos neoplásicos devido à sua interação com o corpo, que dá origem a elétrons que ionizam o meio e criam efeitos químicos, como a hidrólise da água 
e a ruptura das cadeias de ácido desoxirribonucleico (DNA), levando à incapacidade de divisão da célula até a sua morte por inativação (Chaachouay et al., 2011).

Embora o tratamento com a radioterapia seja muito eficiente e realizado da maneira mais conservadora possível, muitas vezes os efeitos colaterais aos tecidos adjacentes são inevitáveis e, embora muitos possam ser transitórios ou intermediários, outros podem ser tardios e irreversíveis (Kielbassa et al., 2006). Dentre os principais efeitos colaterais da radioterapia na cavidade bucal, pode-se citar: mucosite, xerostomia, hipo ou disgeusia, trismo, dor orofacial, alteração do ligamento periodontal, alterações microvasculares, necrose de tecidos moles, osteorradionecrose e "cárie de radiação". A "carie de radiação" apresenta características singulares que a diferem das lesões de cárie convencionais, tais como uma progressão rápida e o acometimento de locais pouco suscetíveis como a porção incisal, a cervical e as cúspides (Kielbassa et al., 2006; Silva et al., 2009; Beech et al., 2014).

Além dos efeitos colaterais acima citados, diversos estudos já demonstraram que a radioterapia é capaz de ocasionar alterações na estrutura dental, tanto no esmalte quanto na dentina como: diminuição da microdureza (Jansma et al., 1988; Kielbassa et al., 1997; Walker et al., 2011) ou aumento da mesma (De Siqueira Mellara et al., 2014; Goncalves et al., 2014), aumento da solubilidade (Markitziu et al., 1986), atrofia dos processos odontoblásticos e obliteração de túbulos dentinários (Kielbassa, 2000), redução da estabilidade da junção amelodentinária (Pioch, Golfels e Staehle, 1992; Kielbassa et al., 1997), destruição de colágeno (Springer et al., 2005; Goncalves et al., 2014), desorganização do esmalte e da dentina resultando em uma superfície dental amorfa (De Siqueira Mellara et al., 2014; Goncalves et al., 2014) e presença de fendas e túbulos dentinários destruídos e/ou colabados (Gonçalves et al., 2014).

Pacientes com câncer de cabeça e pescoço geralmente apresentam cavidade bucal em condições precárias de saúde (Kielbassa et al., 2006; Joshi, 2010; Beech et al., 2014) e a realização do tratamento odontológico prévio ao início da radioterapia de cabeça e pescoço é de extrema importância (Vissink et al., 2003; Joshi, 2010; Beech et al., 2014). 
Entretanto, muitas vezes, o período entre o diagnóstico do câncer e o início do tratamento antineoplásico é curto e insuficiente para tratamentos odontológicos mais complexos, o que leva a mudanças do que seria um tratamento odontológico "ideal". Mesmo assim, é imperativo que se elimine ou, ao menos, reduza-se os focos de infecção presentes na cavidade bucal, bem como remova-se os dentes com prognóstico duvidoso para evitar exodontias futuras, visto que estas podem levar a osteoradionecrose (Vissink et al., 2003; Joshi, 2010; Beech et al., 2014). Idealmente, dentes com prognóstico duvidoso deveriam ser extraídos três semanas antes do início da radioterapia, para cicatrização (Vissink et al., 2003; Kielbassa et al., 2006; Joshi, 2010; Beech et al., 2014).

Outros problemas odontológicos como próteses mal adaptadas, dentes e restaurações com bordas afiladas e cortantes também devem ser reparados, visto que podem traumatizar a mucosa, aumentando o risco de lesãoes bucais traumáticas, de infecções e podendo agravar a mucosite (Kielbassa et al., 2006; Joshi, 2010).

Quanto às lesões de cárie dental, que são frequentes nestes pacientes, visto que esses apresentam em sua maioria saúde bucal precária, é importante que as mesmas sejam submetidas a tratamento previamente à radioterapia (Joshi, 2010; Beech et al., 2014). Entretanto, é pouco abordado na literatura específica qual o momento mais oportuno para a realização de procedimentos restauradores definitivos nestes pacientes e qual o material de escolha a ser utilizado, não existindo nenhum protocolo que estabeleça tais diretrizes. Outro fator que deve ser considerado é que novas lesões de cárie podem aparecer durante e pós pós radioterapia de cabeça e pescoço, as chamadas "cárie de radiação", as mesmas dúvidas permanecem, ou seja, qual material restaurador se comportará da melhor maneira e se a adesão dos materiais restauradores aos tecidos dentais mineralizados, após a radioterapia, será equivalente à dos tecidos dentais anteriormente a mesma.

Com relação aos materiais restauradores, já foi demonstrado que o cimento de ionômero de vidro (CIV) convencional não apresenta resultados muito favoráveis quando utilizado em pacientes submetidos à radioterapia de cabeça e pescoço (Hu et al., 2002) e que o amálgama de prata não é uma opção considerável, pois pode aumentar a quantidade 
de radiação secundária devido à sua densidade e número atômico (Schratter-Sehn et al., 1992). Sendo assim, os materiais restauradores resinosos, que utilizam sistemas adesivos, parecem ser os mais indicados para restaurações em pacientes submetidos à esse tipo de tratamento radioterápico (Mccomb et al., 2002).

Assim é importante saber que existem dois tipos de sistemas adesivos que são empregados de diferentes maneiras: etch \& rinse e self-etch (Kanca, 1992). No sistemas etch \& rinse a smear layer, que é basicamente composta por cortes de fibras colágenas mineralizadas, é removida por meio do condicionamento ácido e o substrato dental é desmineralizado; posteriormente o ácido é removido por meio de enxágue e o sistema adesivo é aplicado ao substrato condicionado completando, assim, o protocolo de adesão (Nakabayashi e Pashley, 2000; Tay e Pashley, 2001; Pashley et al., 2011). No esmalte este condicionamento ácido tem a finalidade de limpar o esmalte, remover a smear layer e aumentar microscopicamente a rugosidade (Retief et al., 1986; Frankenberger e Tay, 2005; Pashley et al., 2011); já na dentina o objetivo é aumentar a porosidade intertubular, permitindo a infiltração do monômero (Nakabayashi e Pashley, 2000), sendo recomendado que a dentina condicionada não seja seca antes da aplicação do sistema adesivo, pois uma sobre secagem pode prejudicar a penetração dos monômeros (Kanca, 1992; Pioch et al., 1999; Ermis et al., 2009).

No sistema self-etch, a smear layer é mantida e usada como substrato de adesão, sendo o sistema adesivo aplicado sobre a smear layer por um período de tempo determinado pelo fabricante, sem enxágue posterior, visando incorporará-la à camada híbrida, que é formada no substrato dental pela desmineralização da superfície, seguida pela infiltração de monômeros e subsequente polimerização (Nakabayashi, Kojima e Masuhara, 1982; Tay e Pashley, 2001; Peumans et al., 2010). Este sistema vem sendo mais empregado por apresentar melhores resultados do que o etch \& rinse simplificados (Tay e Pashley, 2001; De Munck, Vargas, et al., 2005; Frankenberger e Tay, 2005; Van Landuyt et al., 2006). 
Os poucos estudos realizados analisando a influência da radiação no sistema de adesão dos materiais restauradores ao substrato dental, sendo que estes apresentam resultados contraditórios quanto ao efeito da radioterapia na adesão ao substrato dental (Gernhardt et al., 2001; Naves et al., 2012; Galetti et al., 2014). Desta forma, em função da ausência de consenso nos trabalhos publicados na literatura específica, e que apenas um estudo avaliou a influência da radiação ao sistema adesivo aplicado em esmalte de dentes permanentes (Naves et al., 2012), há necessidade de mais estudos, a fim de que se possa ser desenvolvido um protocolo, que determine qual tipo de sistema adesivo deve ser indicado e qual o melhor momento (pré ou pós radioterapia) para que estas restaurações sejam realizadas, em pacientes portadores de câncer na região de cabeça e pescoço. 
2. Proposição 



\section{PROPOSIÇÃo}

\section{Objetivos gerais}

O objetivo do presente estudo foi avaliar o efeito da simulação do tratamento radioterápico, em diferentes momentos, na adesão de materiais resinosos e na interface adesiva ao esmalte e à dentina de dentes permanentes.

\section{Objetivos Específicos}

- Avaliar o efeito da radiação no período da realização da restauração do elemento dental (esmalte e dentina) por meio do teste de cisalhamento.

- Analisar qualitativamente a interface de união compósito/substrato dental por meio de microscopia confocal a laser e microscopia eletrônica de varredura (MEV).

- Analisar longitudinalmente, por meio de microscopia confocal a laser, as alterações morfológicas ocorridas na superfície do substrato dental durante o processo de radiação, 

3. Xateriale Xetodos 



\section{MATERIAL e MÉtodos}

Este estudo foi previamente submetido à apreciação e aprovação do Comitê de Ética em Pesquisa da Faculdade de Odontologia de Ribeirão Preto (Processo n 570.705) (Anexo 1) e os dentes obtidos junto ao Banco de Dentes da mesma faculdade.

\section{Delineamento Experimental}

O presente estudo foi fatorial com período da realização da restauração em 4 níveis [controle sem irradiação, antes da irradiação, imediatamente após a irradiação e 6 meses após a irradiação) e sistema adesivo em 2 níveis (etch \& rinse e self-etch). Para ambos os fatores foi realizado o estudo para esmalte e dentina de dentes permanentes, que não foram comparados entre si, pois a composição dos substratos é distinta. As unidades experimentais foram 120 fragmentos de esmalte e 120 fragmentos de dentina, divididos aleatoriamente em 4 grupos/8 subgrupos experimentais.

O estudo foi realizado de acordo com um delineamento em blocos completos casualizados. A variável de resposta quantitativa foi a resistência adesiva expressa em MPa e o tipo de fratura. Qualitativamente a microscopia confocal a laser foi utilizada para análise morfológica longitudinal para evidenciar as possíveis alterações do substrato durante a irradiação. A microscopia eletrônica de varredura foi utilizada para analisar as interfaces dente/restauração.

\section{Seleção dos Dentes}

A amostra foi constituída por terceiros molares permanentes humanos, superiores e inferiores, recém-extraídos e hígidos, obtidos junto ao Banco de Dentes da Faculdade de Odontologia de Ribeirão Preto da Universidade de São Paulo, armazenados em água destilada, à temperatura de $4^{\circ} \mathrm{C}$. Foram selecionados dentes sem facetas de desgaste e com rizogênese completa, para que houvesse padronização na idade e maturação do esmalte dental. 
Os dentes foram submetidos à profilaxia com pasta de pedra-pomes e água, com o auxílio de escova tipo Robinson montada em micromotor, em baixa rotação. A seguir, com o auxílio de uma sonda exploradora e de um estereomicroscópio (Nikon Inc. Instrument Group, Melville, NY, USA) em aumento de 10x, foi realizado o exame tátil e visual do espécime, sendo selecionados apenas os dentes que não apresentavam trincas, fraturas, lesões de cárie ou anomalias de estrutura, e que não tivessem sido submetidos a tratamento endodôntico ou químico (dentes clareados). Os dentes que não respeitavam os critérios de inclusão foram devolvidos ao Banco de Dentes e substituídos até que o número amostral estipulado fosse atingido $(n=60)$.

Os dentes selecionados foram armazenados em solução de timol a $0,1 \%$ supersaturada, durante 1 semana sendo, a seguir, lavados em água corrente por 24 horas. Após esse período, os dentes foram colocados em recipientes contendo água destilada e mantidos em refrigerador à temperatura de aproximadamente $4^{\circ} \mathrm{C}$, até $\mathrm{o}$ início da confecção dos espécimes.

\section{Confecção dos Espécimes}

Os dentes previamente selecionados foram inicialmente seccionados $1 \mathrm{~mm}$ abaixo da junção amelocementária, com disco diamantado adaptado em máquina de corte (Miniton, Struers A/S, Copenhagen, Dinamarca), sob refrigeração, para remoção do remanescente radicular.

Cada coroa dental foi então seccionada no sentido mésio/distal e vestíbulo-lingual, obtendo-se quatro secções, num total de 240 fragmentos. Os fragmentos foram incluídos em resina autopolimerizável (JET-Clássico Artigos Odontológicos, São Paulo-SP, Brasil), utilizando anéis de cloreto de polivinil $(2,1 \mathrm{~cm}$ de diâmetro e $1,1 \mathrm{~cm}$ altura). A seguir foram separados em grupos de acordo com a superfície que foi exposta: esmalte $(n=120)$ ou dentina $(n=120)$. Após a polimerização da resina, as superfícies do esmalte e da dentina foram lixadas com lixas de carbureto de silício \#280 (Norton/Saint-Gobain Abrasivos Ltda., Guarulhos- SP, Brasil) em uma politriz (DP-9U2, Struers A/S, Copenhagen, Dinamarca), em 
baixa velocidade, para obter uma superfície plana de esmalte e de dentina. A seguir os fragmentos incluídos foram lixados em politriz com lixas de granulação \# 400 e \# 600, por 30s, a fim de se obter superfícies planas e ao mesmo tempo padronizar a smear layer (Figura 1).

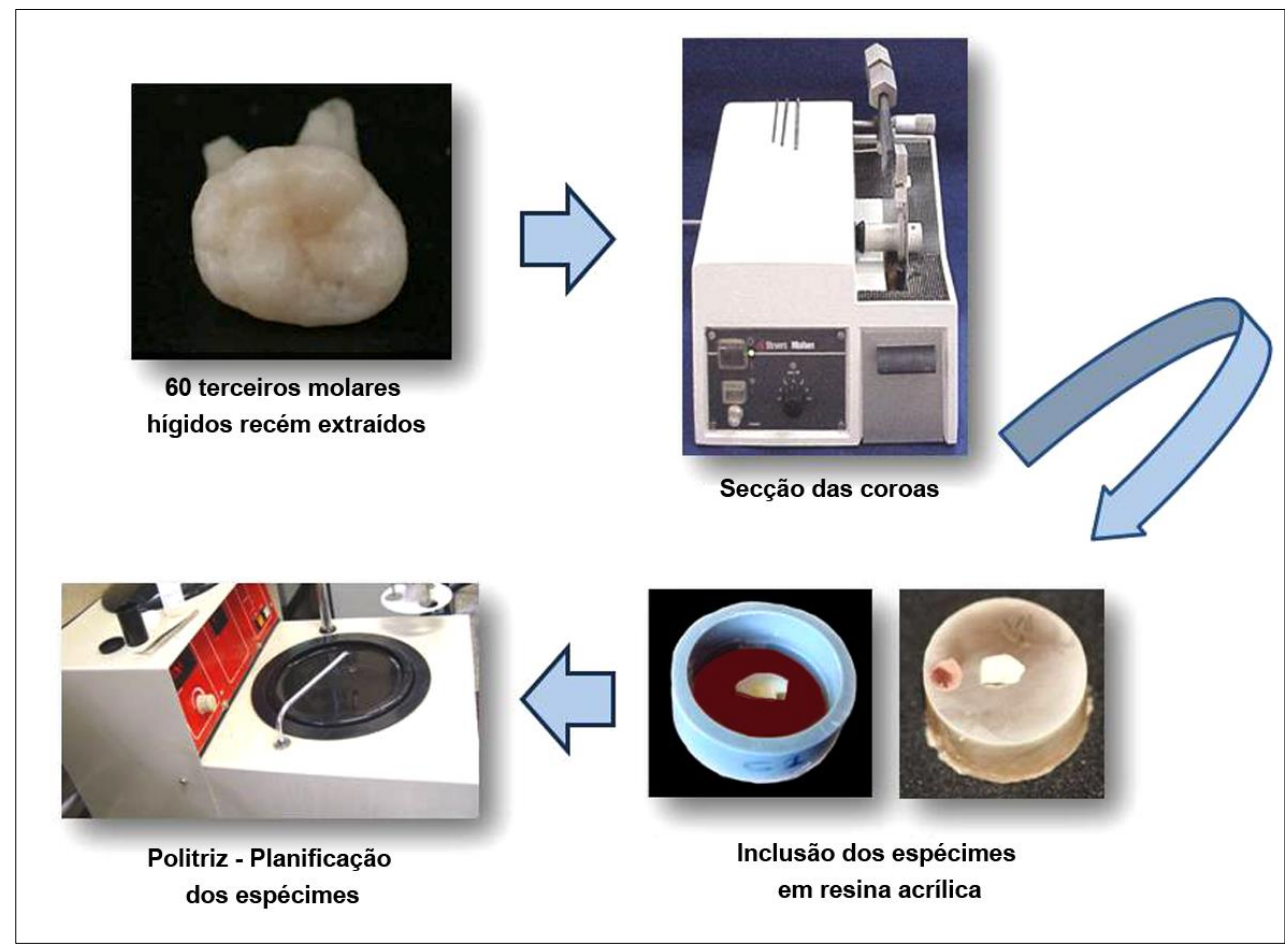

Figura 1. Inclusão dos fragmentos dentais em resina acrílica e planificação.

Os espécimes, tanto em esmalte como em dentina, foram divididos aleatoriamente em grupos 4 grupos (n=30): G1 (controle) - substrato sem irradiação + procedimento restaurador; G2 - procedimento restaurador realizado previamente à irradiação, G3 - procedimento restaurador realizado após a irradiação; e G4 procedimento restaurador realizado 6 meses após a irradiação. Cada um dos grupos foi dividido em 2 subgrupos, sendo que no subgrupo "A" (SGA) foi empregado para o procedimento restaurador o adesivo Adper ${ }^{\mathrm{TM}}$ Single Bond 2 (3M/ESPE, St Paul, MN 55144, USA); e no subgrupo "B" (SGB) utilizou-se o adesivo Clearfil SE Bond (Kuraray CO.LTD., Umeda, Osaka Japan) (Figura 2) (Tabela 1). 


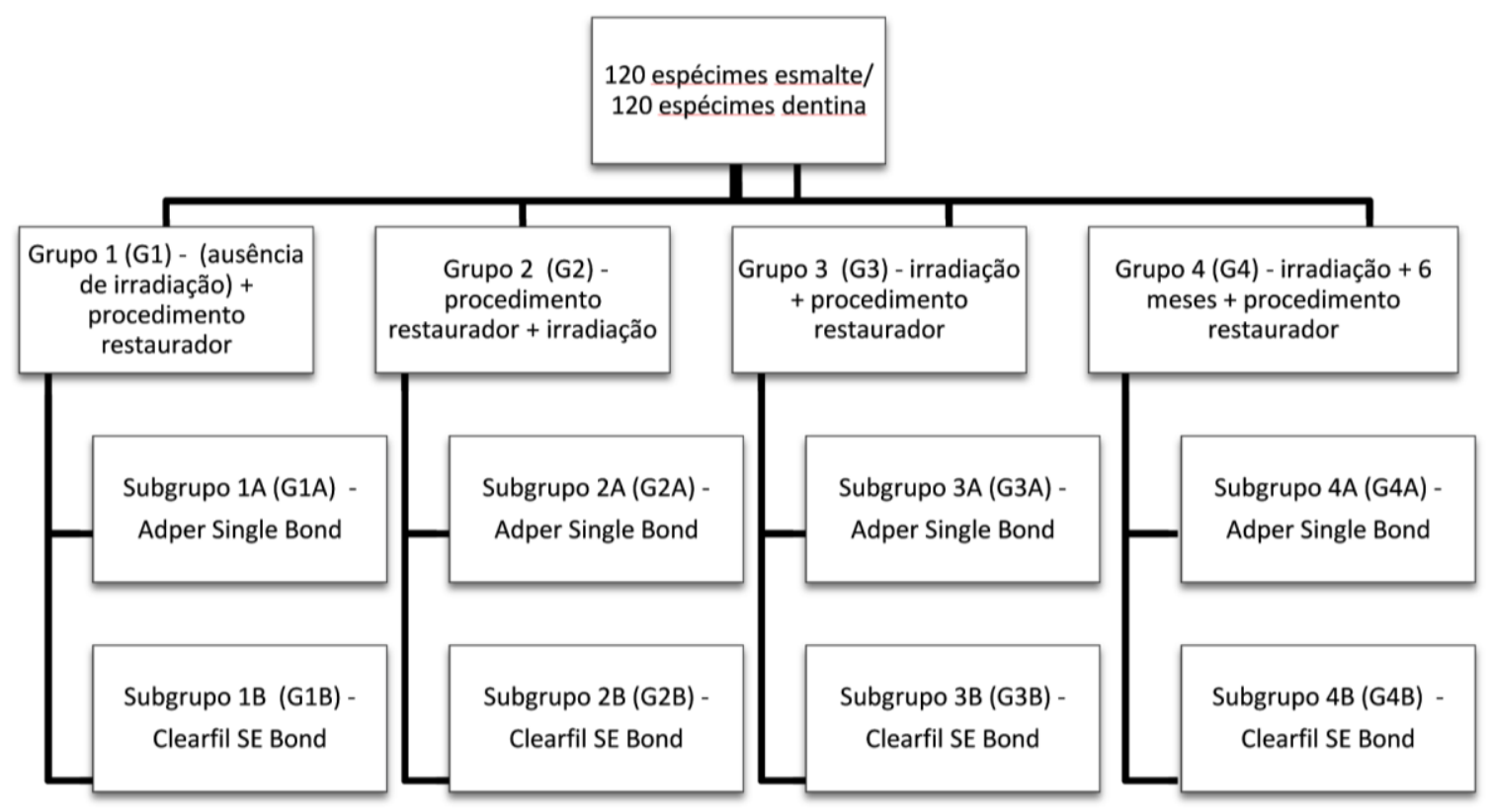

Figura 2. Divisão dos grupos e subgrupos.

Tabela 1. Nome comercial, fabricante e composição dos adesivos.

Condicionador: ácido fosfórico a $37 \%$

Bis-GMA, 2-hydroxyetil metacriato

Adper $^{\mathrm{TM}}$ Single Bond 2 (etch \& rinse de 2 passos)

Clearfil SE Bond (self-etch de 2 passos)
3M/ESPE, St Paul, MN 55144, USA

Kuraray CO.LTD., Umeda. Osaka Japan
(HEMA), Diuretano dimetacrilato, Copolímero do ácido polialcenóico canforoquinona, Água, Etanol, Glicerol 1,3 dimetacrilato e 10\% em peso de nanopartículas de sílica $(5 \mathrm{~nm})$

\begin{tabular}{|c|c|}
\hline $\begin{array}{ll}\text { Primer: } 10 & \text { MDP; } \\
\text { dimetacrilatos } & \\
\text { canforoquinona; } & \text { N,N } \\
\text { ptoluidina; água. } & \end{array}$ & $\begin{array}{r}\text { HEMA; } \\
\text { hidrofílos; } \\
\text { dietanol- }\end{array}$ \\
\hline $\begin{array}{l}\text { Adesivo: } 10 \text { MDP; } \\
\text { HEMA; dimetacrilatos } \\
\text { canforoquinona; N,N } \\
\text { ptoluidina; sílica } \\
\text { silanizada }\end{array}$ & $\begin{array}{r}\text { Bis-GMA; } \\
\text { hidrófobos; } \\
\text { dietanol- } \\
\text { coloidal }\end{array}$ \\
\hline
\end{tabular}

A superfície dos espécimes de esmalte e dentina foi coberta com uma fita adesiva (Scoth, 3M/ESPE do Brasil Ltda, Sumaré - SP, Brasil), com um orifício circular de $2 \mathrm{~mm}$ de diâmetro confeccionado por meio de perfurador modificado, com a finalidade de delimitar a área restaurada e então divididos aleatoriamente em 2 subgrupos (Figura 3). 
SGA - Para a realização do procedimento restaurador foi utilizado o sistema adesivo etch \& rinse de 2 passos Adper ${ }^{T M}$ Single Bond 2 (3M/ESPE, St Paul, MN 55144, USA), seguindo-se as instruções do fabricante. Primeiramente, foi aplicado o ácido fosfórico a 37\% (Etching gel- 3M Dental Products - ST Paul, MN 55144-USA), por 15s para o esmalte e 10s para a dentina, na superfície dental previamente delimitada, que foi então removido com spray ar/água por 30 s. O excesso de umidade foi removido com papel absorvente, permitindo que o substrato ficasse hidratado para receber o agente adesivo, que foi aplicado em duas camadas consecutivas com tempo de espera de 15s e fotopolimerizado por 20 s com 0 fotopolimerizador JetLite 4000 (J. Morita - 9 Manson Irvine, CA 92618 -USA), com potência de $1000 \mathrm{~mW} / \mathrm{cm}^{2}$.

SGB - Para realização do procedimento restaurador foi utilizado o sistema adesivo selt-etch Clearfil SE Bond (Kuraray CO.LTD., Umeda. Osaka Japan), seguindo-se as instruções do fabricante. Primeiramente foi efetuada a aplicação do primer na superfície dental delimitada, e aguardando-se 20s para depois aplicar-se o bond, aguardando o tempo de 10s para fotopolimerizar o espécime por 10s com o fotopolimerizador JetLite 4000 (J. Morita - 9 Manson Irvine, CA 92618 -USA) com potência de $1000 \mathrm{~mW} / \mathrm{cm}^{2}$.

Os sistemas adesivos foram cuidadosamente aplicados sobre a superfície dental com aplicadores descartáveis (Cavibrush fino - FGM) para evitar excessos, e também a fim de evitar que o adesivo se agregasse ao longo das bordas da fita isolante, o que poderia comprometer a distribuição das tensões durante o ensaio e, consequentemente, a validade dos resultados (Figura 3).

Em seguida, os espécimes foram fixados individualmente em um dispositivo metálico com base ajustável, que permitiu manter a superfície de esmalte ou dentina paralela a uma base de superfície plana. Uma matriz de Teflon biseccionada foi posicionada sobre o bloco dente/resina, proporcionando assim uma cavidade cilíndrica com $4 \mathrm{~mm}$ de altura e $2 \mathrm{~mm}$ de diâmetro, coincidindo com a delimitação de dentina e esmalte que receberam a aplicação dos adesivos. Em seguida, a resina composta Z350 (3M dental Products St Paul, MN 55144 - USA) foi inserida na matriz em 3 incrementos e fotopolimerizada por $20 \mathrm{~s}$ cada incremento, com 0 fotopolimerizador JetLite 4000, obtendo-se assim, um cilindro com $2 \mathrm{~mm}$ de diâmetro coincidente com o sítio de adesão pré-determinado pela fita adesiva (Figura 3). 
Após o preenchimento da cavidade, o espécime foi retirado do dispositivo metálico, a matriz aberta e separada, e a fita adesiva retirada, ficando os cilindros de resina composta aderidos ao esmalte ou à dentina. Em seguida os espécimes foram armazenados por $24 \mathrm{~h}$ em água destilada a $37^{\circ} \mathrm{C}$, até serem expostos à radiação e/ou serem submetidos ao teste cisalhamento, de acordo com o grupo a que pertencia (Figura 3).

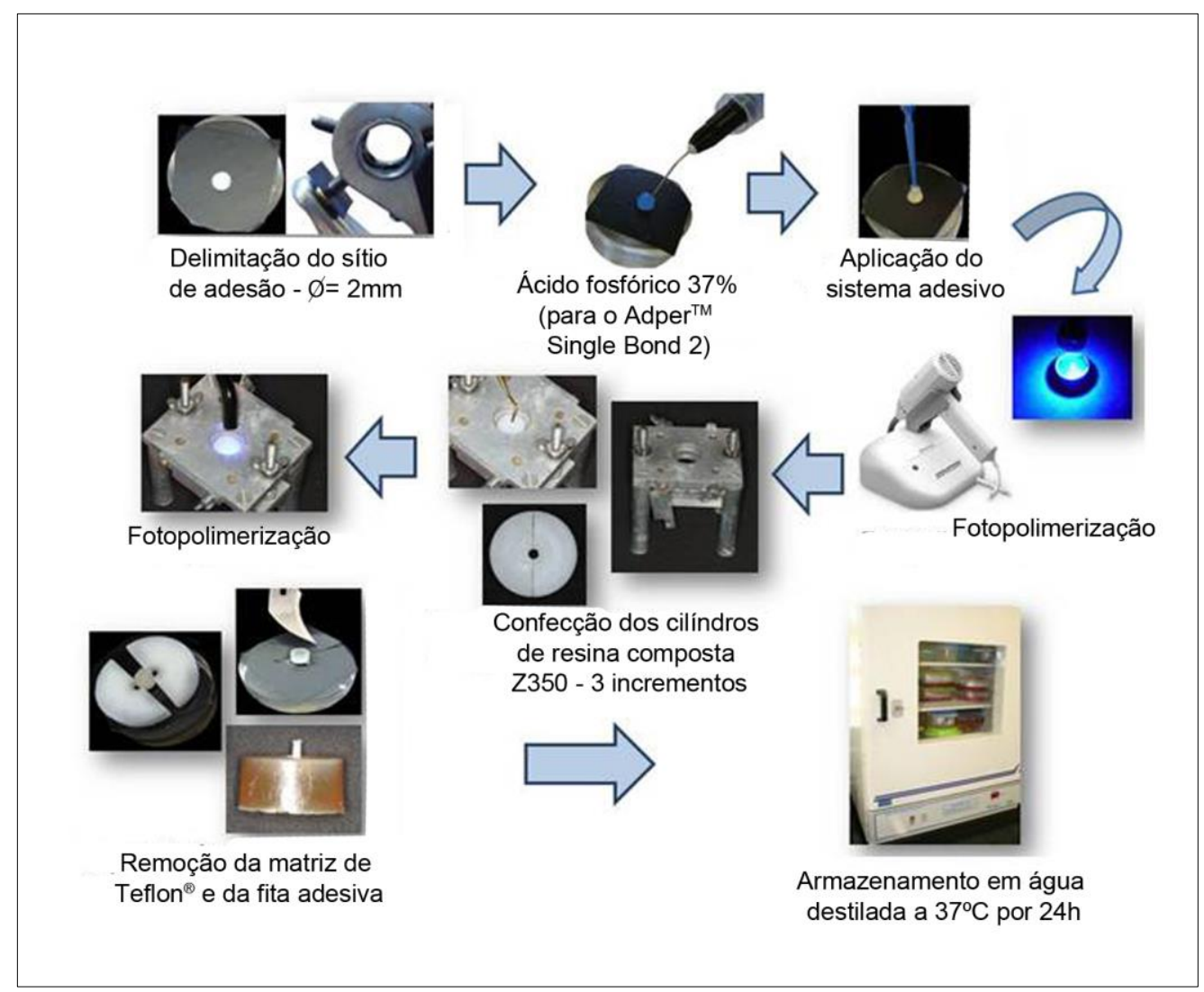

Figura 3. Confecção dos cilindros de resina composta.

\section{Procedimento de Irradiação dos Espécimes}

Os corpos de prova foram irradiados no Serviço de Radioterapia do Hospital das Clínicas da Faculdade de Medicina de Ribeirão Preto da Universidade de São Paulo. Durante o procedimento de irradiação, os corpos de prova foram dispostos em caixa plástica de maneira que todos os corpos de prova recebessem radiação e imersos em água deionizada/destilada, com o intuito de mantê-los em ambiente úmido, simulando a cavidade bucal. Ao final do procedimento, a água deionizada/destilada foi desprezada e os corpos de prova foram mantidos em saliva artificial, em estufa a $37^{\circ} \mathrm{C}$ até o próximo ciclo de irradiação, 
quando então a saliva foi novamente substituída por água deionizada/destilada. O uso da saliva artificial durante a irradiação foi evitada, devido à sua alta concentração de íons, o que poderia interferir na radiação direta por unidade de área.

Os espécimes foram submetidos à fração de dose de 2Gy/dia, durante 5 dias consecutivos, até atingirem a dose total de 60Gy, em um total de 30 frações por 6 semanas (Tabela 2) (Kielbassa, 2000; Bulucu et al., 2009; Soares et al., 2010; Soares et al., 2011; De Siqueira Mellara et al., 2014; Goncalves et al., 2014; Martins et al., 2015; Santin et al., 2015). A fonte de raios- $X$ foi um irradiador dedicado a pesquisas biológicas (RS 2000, Rad Fonte Technologies, Inc., Suwanee, GA, USA), com energia de $200 \mathrm{kVp}$ e $25 \mathrm{~mA}$ e filtro padrão de cobre de $0,3 \mathrm{~mm}$. Os raios- $X$ gerados sob esta condição possuem um espectro com energia mínima de $95 \mathrm{kV}$ até $200 \mathrm{kV}$ máximo de energia e a metade do valor do feixe com $0,62 \mathrm{~mm}$ de cobre. O gradiente de dose destes raios-X em tecido é de cerca de $10 \%$ a $0,5 \mathrm{~cm}$ de profundidade. As caixas foram alinhadas equidistantes do centro do feixe e interior do cone para garantir taxa de dose uniforme (aproximadamente 2,85Gy/min) e entrega total da dose por fração. O controle de qualidade foi realizado utilizando dosímetros Nanodot (Landauer, Inc., Glenwood, IL, USA), sendo as leituras de dose na superfície das placas utilizadas para calcular os tempos de tratamento "beam-on". Os dosímetros foram colocados sob as caixas irradiadas e calibrados de acordo com as condições de feixe descritos anteriormente.

Após o término da radioterapia, os espécimes foram mantidos em saliva artificial em estufa a $37^{\circ} \mathrm{C}$, durante 24 horas, quando foi realizado o teste de cisalhamento ou procedimento restaurador, de acordo com o grupo.

Tabela 2. Número de ciclos de irradiação, períodos de tempo e doses totais empregadas

\begin{tabular}{ccc} 
Número de ciclos de irradiação & Período de tempo (semanas) & $\begin{array}{c}\text { Dose total } \\
\text { (2Gy por ciclo) }\end{array}$ \\
5 & 1 & $10 G y$ \\
10 & 2 & $20 G y$ \\
15 & 3 & $30 G y$ \\
20 & 4 & $40 G y$ \\
25 & 5 & $50 G y$ \\
30 & 6 & $60 G y$ \\
\hline
\end{tabular}




\section{Ensaio de Resistência ao Cisalhamento}

Para este ensaio os espécimes foram posicionados na máquina de ensaios mecânicos (Instron, Modelo 2519-106, Canton, MA, USA) para que fosse realizado o teste de cisalhamento, onde os cilindros de resina composta foram descolados à velocidade de $0,5 \mathrm{~mm} / \mathrm{min}$ com célula de carga de $20 \mathrm{Kgf}$. Uma ponta ativa em cinzel foi apoiada na interface adesiva/substrato dental e a força aplicada até o momento da fratura, sendo obtido o valor de força máxima do movimento.

A resistência de união ao cisalhamento foi calculada dividindo-se a força máxima registrada durante o ensaio (em $\mathrm{N}$ ) pela área de união dos cilindros de resina composta $\left(3,14 \mathrm{~mm}^{2}\right)$ e os valores expressos em MPa.

\section{Análise do Padrão de Fratura}

As superfícies vestibulares de todos os corpos de prova foram submetidas à microscopia confocal por varredura à laser (LEXT OLS4000, Olympus, Walthan, MA, USA) para determinarr o modo da fratura. Por ser um método não destrutivo, o microscópio confocal à laser permite a análise da superfície dos corpos de prova, por meio de imagens 3D obtidas de áreas representativas de cada grupo. Estas foram distribuídas em tabela de contingência, verificando-se a frequência entre grupos/subgrupos.

Após obtenção das imagens, estas foram classificadas quanto ao modo da fratura (Ramos et al., 2004):

- Fratura adesiva (Ad) - Quando a fratura foi observada entre o sistema adesivo e o substrato dental;

- Fratura coesiva material (CM) - Quando a fratura ocorreu a nível do material restaurador, permanecendo aderido ao substrato dental;

- Fratura coesiva substrato (CS) - Quando a fratura aconteceu sobre a superfície dental removendo parte do substrato dental;

- Fratura mista (M) - Quando em um mesmo corpo de prova houve fratura no substrato dental e na resina (tendo pelo menos $40 \%$ da área de cada tipo de fratura). 


\section{Análise Morfológica Longitudinal da Superfície Dental}

Para esta análise foram selecionados aleatoreamente 10 espécimes ( 5 de dentina e 5 de esmalte) submetidos à microscopia confocal por varredura à laser (LEXT OLS4000, Olympus, Walthan, MA, USA), para que fosse realizada uma análise morfológica durante o processo de radiação sendo, assim, possível avaliar as possíveis alterações que a radiação proporciona na superfície do substrato dental.

Os espécimes foram submetidos à microscopia confocal antes do início do processo de radiação, para avaliação de sua morfologia inicial. Esta análise foi realizada nos aumentos de $172 x, 1074 x$ e $3415 x$ e a área avaliada foi determinada e anotada para que as análises seguintes sempre fossem feitas na mesma região. O mesmo procedimento foi realizado a cada 10Gy, até que se completasse o ciclo de 60Gy, sempre na mesma região.

\section{Análise da Interface Adesiva}

Para este experimento foram selecionados 3 espécimes de cada grupo, que apresentavam fratura coesiva material ou fratura mista e foram seccionados a $2 \mathrm{~mm}$ de espessura com disco diamantado adaptado em máquina de corte (Miniton, Struers A/S, Copenhagen, Dinamarca). Um dos lados foi polido com lixas de carbureto de silício \#600 e \#1200 e alumina 0,3 e 0,05 $\mu$ m Após serem seccionados os espécimes foram submetidos ao seguinte protocolo: fixação (imersão em solução de glutaraldeído a 2,5\% tamponado com solução de cacodilato de sódio a $0,1 \mathrm{M}$ com $\mathrm{pH} 7,4)$ a $4^{0} \mathrm{C}$ por $12 \mathrm{~h}$, lavagem em água destilada por 3min, aplicação de EDTA ativamente na dentina por $1 \mathrm{~min}$, e aplicação de ácido fosfórico a 37\% (Gel Etchant- Kerr Corporation, Orange, USA) no esmalte por 10s, remoção e lavagem com água destilada, limpeza em cuba ultrassônica (UltrasonicCleaner T-1449-D. Odontobrás Ind. e Com., Ribeirão Preto, Brasil) contendo água destilada e deionizada durante 10min, secagem e desidratação em graus crescentes de etanol (Labsynth Ltda., Diadema, Brasil): 25\% (20min), 50\% (20min), 75\% (20min), 95\% (30min) e 100\% (60min). Após a desidratação, os espécimes de dentina foram imersos em solução de HMDS (Hexamethyldisiloxane-Merck KgaA, Darmstadt, D-64293, Alemanha) por 10min para secagem química. 
Depois da secagem, os espécimes foram fixados em stubs com fita adesiva de carbono, de dupla face (ElectronMicroscopySciences, Washigton, EUA) e realizada a cobertura com ouro em aparelho de metalização a vácuo (SDC 050, Bal-Tec AG, Foehrenwg 16, Balzers, Alemanha), com pressão de 0,01mbar, corrente de 40mA, distância de trabalho de $50 \mathrm{~mm}$, tempo de cobertura de 90 s e espessura média de deposição de 20 a 30nm. Em seguida, as secções dentais foram observadas em microscópio eletrônico de varredura (Philips XL30 FEG, Eindhoven, Holanda; disponibilizado pelo DEMa - Laboratório do Departamento de Engenharia de Materiais da Universidade Federal de São Carlos, São Paulo, Brasil) para observação da interface adesiva quanto à presença de tags, camada híbrida, homogeneidade do adesivo e presença de fendas, sendo obtidas eletromicrografias das áreas representativas.

\section{Análise dos Dados}

Os resultados do teste mecânico de cisalhamento, com respostas obtidas em $\mathrm{N}$ e convertidas em MPa, foram submetidos a teste para verificação da normalidade dos dados (teste de Shapiro-Wilk), e para verificação da homogeneidade das variâncias realizou-se o teste de Levene. Os resultados para o grupo esmalte apresentaram distribuição normal e homogênea, o que não ocorreu para o grupo dentina, onde foi necessária a transformação de dados por meio da raiz quadrada dos valores, visto que essa não modifica a tendência mantendo, assim a proporcionalidade dos dados.

Assim, os dados obtidos no teste de resistência ao cisalhamento entre grupos/subgrupos experimentais foram analisados por Análise de Variância dois critérios (tempos de restauração e sistema adesivo). Para diferenciação das médias realizou-se o teste de Tukey.

Os dados foram analisados por meio do programa estatístico Bioestat 5.3 e o nível de significância adotado foi de 5\%.

As imagens obtidas em microscopia confocal à laser e microscopia eletrônica de varredura da área de interface compósito/esmalte foram avaliadas qualitativamente. 
4. Resultados 



\section{Resultados}

\section{Resistência Adesiva ao Cisalhamento}

Esmalte

$\mathrm{Na}$ análise dos dados para o fator sistemas adesivos observou que o Clearfill SE Bond (SGB) apresentou maior média $(20,05)$ quando comparado ao Adper $^{\mathrm{TM}}$ Single Bond 2 (SGA) $(14,84)$ sendo esta diferença estatisticamente significante $(p<0,05)$ (Figura 4).

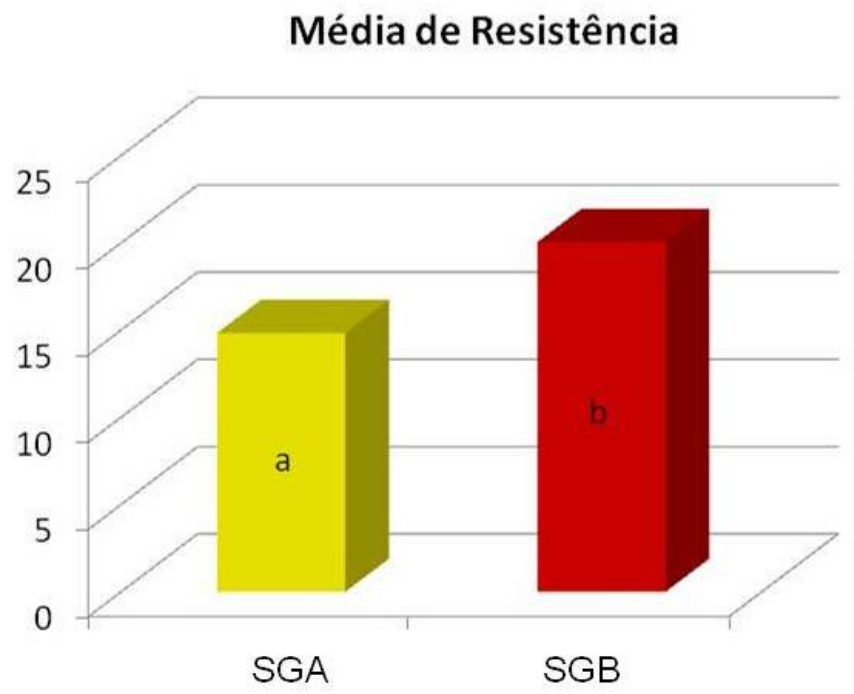

Figura 4. Média da resistência adesiva ao esmalte para os diferentes sistemas adesivos (letras iguais = similaridade estatística).

Com relação fator tempo de restauração observou que houve diferença significante entre os grupos, sendo a menor média $(10,09)$ observada no grupo restaurado e depois irradiado (G2), e estatisticamente diferente dos demais grupos estudados $(p<0,05)$. O grupo restaurado após 6 meses (G4), o grupo controle (G1) e o grupo irradiado e depois restaurado (G3) foram semelhante entre si $(p>0,05)$ (Figura 5). 


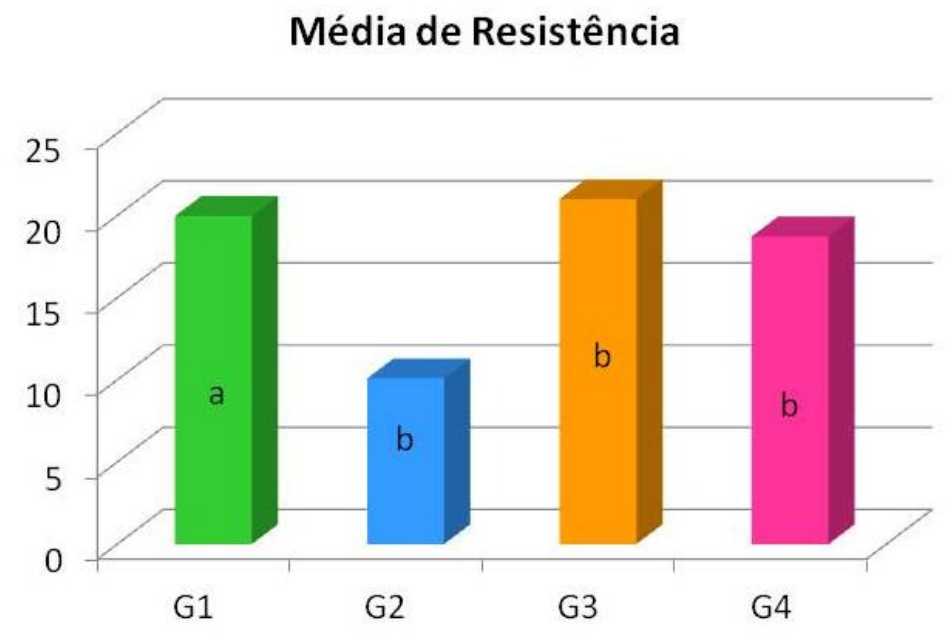

Figura 5. Média de resistência adesiva ao esmalte para os diferentes tempos de restauração estudados (letras iguais = similaridade estatística).

Os grupos G1 e G2 não apresentaram diferença estatística significante entre os dois sistemas adesivos testados $(p>0,05)$, para os grupos G3 e G4 houve diferença estatisticamente significante entre o SGA e SGB, onde o último apresentou valores mais altos, mostrando-se mais eficiente $(p<0,05)$ (Tabela 2).

Quando analisado o desempenho do SGA em relação aos diferentes tempos o G2 não apresentou diferença estatisticamente significante em relação ao grupo G3 ( $p>0,05)$, mas mostrou diferença estatisticamente significante quando comparado aos grupos G4 e G1 $(p<0,05)($ Tabela 2).

Quando comparado o SGB quanto aos diferentes tempos, o grupo G2 apresentou diferença estatisticamente significante em relação aos grupos G3 e G4 $(p<0,05)$ e o grupo G3 apresentou diferença significante em relação aos outros três grupos, mostrando resultados melhores quando comparado aos demais $(p<0,05)($ Tabela 2$)$.

Tabela 2. Diferença entre a resistência adesiva ao cisalhamento (MPa) dos dois sistemas adesivos nos diferentes momentos de restauração em esmalte.

\begin{tabular}{ccc} 
& SGA & SGB \\
\hline G1 & 20,99 b A & 18,95 ab A \\
G2 & 14,93 ab B & 27,06 c A \\
G3 & 7,98 a A & 12,19 a A \\
G4 & 15,46 b B & 22,03 bc A \\
\hline
\end{tabular}




\section{Dentina}

$\mathrm{Na}$ análise dos dados pode-se observar que quando avaliado o fator sistemas adesivos o grupo SGB apresentou maior média $(19,00)$ quando comparado ao SGA $(11,95)$, sendo esta diferença estatisticamente significante $(p<0,05)$ (Figura 6).

\section{Média de resistência}

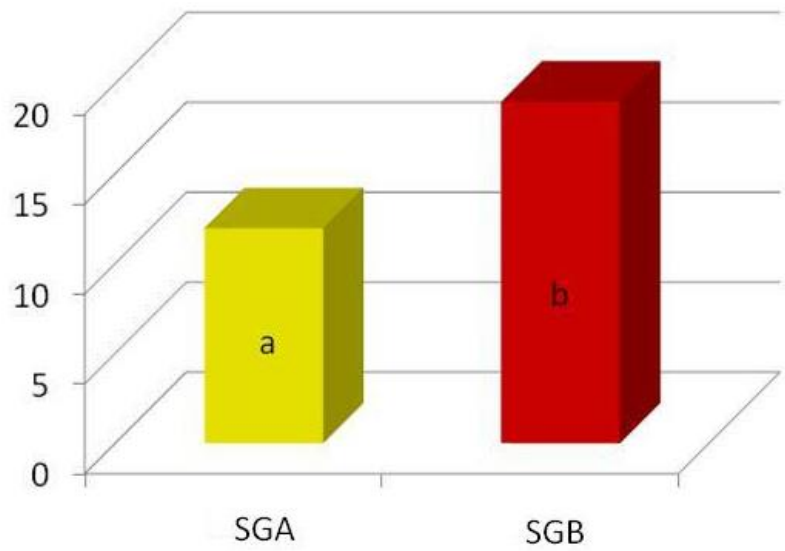

Figura 6. Média da resistência adesiva da dentina para os diferentes sistemas adesivos (letras iguais = similaridade estatística).

Para o fator tempo de restauração houve diferença significante entre os grupos $(p<0,05)$, tendo a menor média $(8,33)$ o grupo restaurado e depois irradiado $(G 2)$, porém não apresentou diferença estatística quando comparado ao grupo irradiado e depois restaurado (G3) ( $p>0,05)$, sendo estatisticamente diferente dos demais grupos estudados $(p<0,05)$. $O$ grupo restaurado após 6 meses (G4), o grupo controle (G1) e o irradiado e depois restaurado (G3) foram semelhante entre si $(p>0,05)$ (Figura 7$)$. 


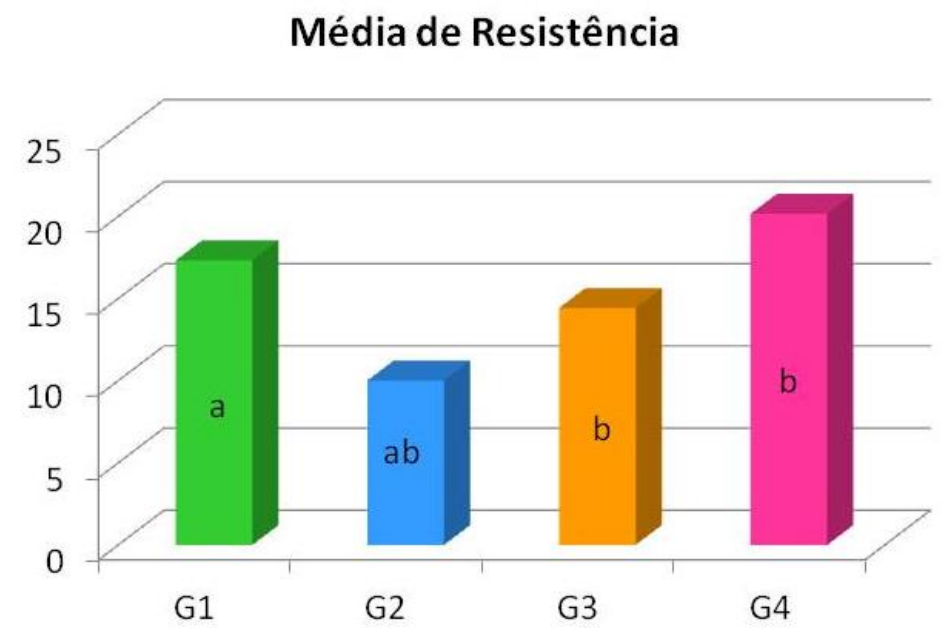

Figura 7. Média de resistência adesiva a dentina para os diferentes tempos de restauração estudados (mesma letra - similaridade estatística).

Para os grupos G1 e G2 não houve diferença estatística entre ambos os sistemas adesivos testados ( $p>0,05)$, para os grupos G3 e G4 houve diferença estatisticamente significante entre os sistemas adesivos $(p<0,05)$, onde o SBG apresentou valores mais altos, mostrando-se mais eficiente (Tabela 3).

Quando analisado o desempenho do SGA em relação aos diferentes tempos o grupo G1 não apresentou diferença estatisticamente significante em relação aos grupos G2 e G4 ( $p>0,05)$, mas houve diferença estatisticamente significante quando comparado ao grupo G3 $(p<0,05)$. (Tabela 3).

No SGB, nos diferentes tempos, os grupos G3 e G2 não apresentaram diferença estatística em relação ao G1 ( $p>0,05)$, por sua vez o grupo G4 apresentou o melhor resultado e diferença significante quando comparado aos outros três grupos $(p<0,05)$ (Tabela 3).

Tabela 3. Diferença entre a resistência adesiva ao cisalhamento ( $\mathrm{MPa}$ ) dos dois sistemas adesivos nos diferentes momentos de restauração em dentina

$\begin{array}{ccc} & \text { SGA } & \text { SGB } \\ \text { G1 } & 17,88 \mathrm{~b} \mathrm{~A} & 16,22 \mathrm{ab} \mathrm{A} \\ \text { G3 } & 8,33 \mathrm{~A} \mathrm{a} & 11,70 \mathrm{a} \mathrm{A} \\ \text { G4 } & 10,03 \mathrm{ab} \mathrm{B} & 18,80 \mathrm{~b} \mathrm{~A} \\ \end{array}$

Nota: Letras minúsculas: comparação na coluna (letras iguais = similaridade estatística).; Letras maiúsculas: comparação na linha (letras iguais = similaridade estatística). 


\section{Análise do Padrão de Fratura}

\section{Esmalte}

$\mathrm{Na}$ análise da porcentagem dos padrões de fratura para os grupos de esmalte percebeu-se que a fratura adesiva foi predominante em todos os grupos. Contudo para o G3B (grupo irradiado e imediatamente restaurado com Adper Single Bond 2), observou-se uma alta incidência da fratura do tipo coesiva material (Figura 8).

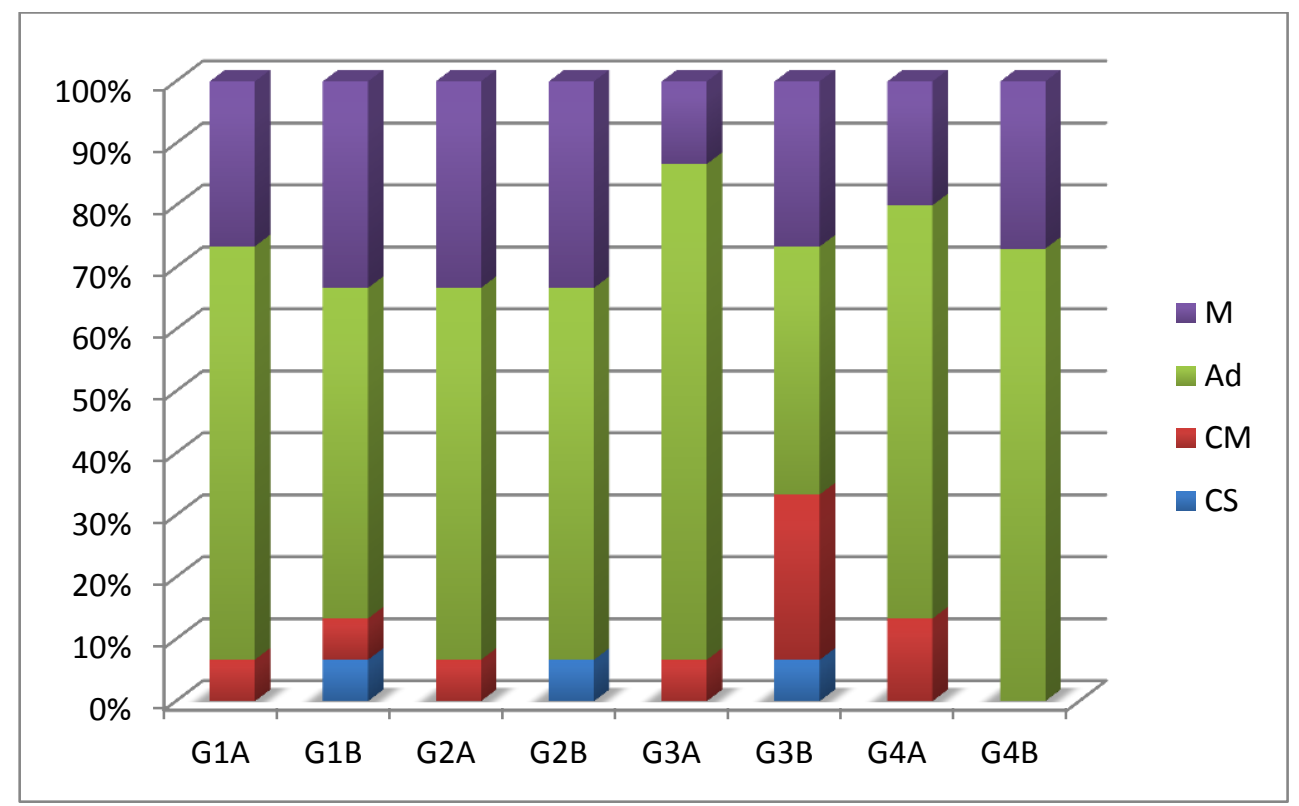

Figura 8. Média dos padrões de fraturas no esmalte.

\section{Dentina}

Quando avaliou-se as porcentagens dos padrões de fratura para os grupos de dentina observou-se que a fratura adesiva foi predominante em todos os grupos. Sendo que para o G3B observou-se uma alta prevalência também do padrão de fratura misto (Figura 9). 


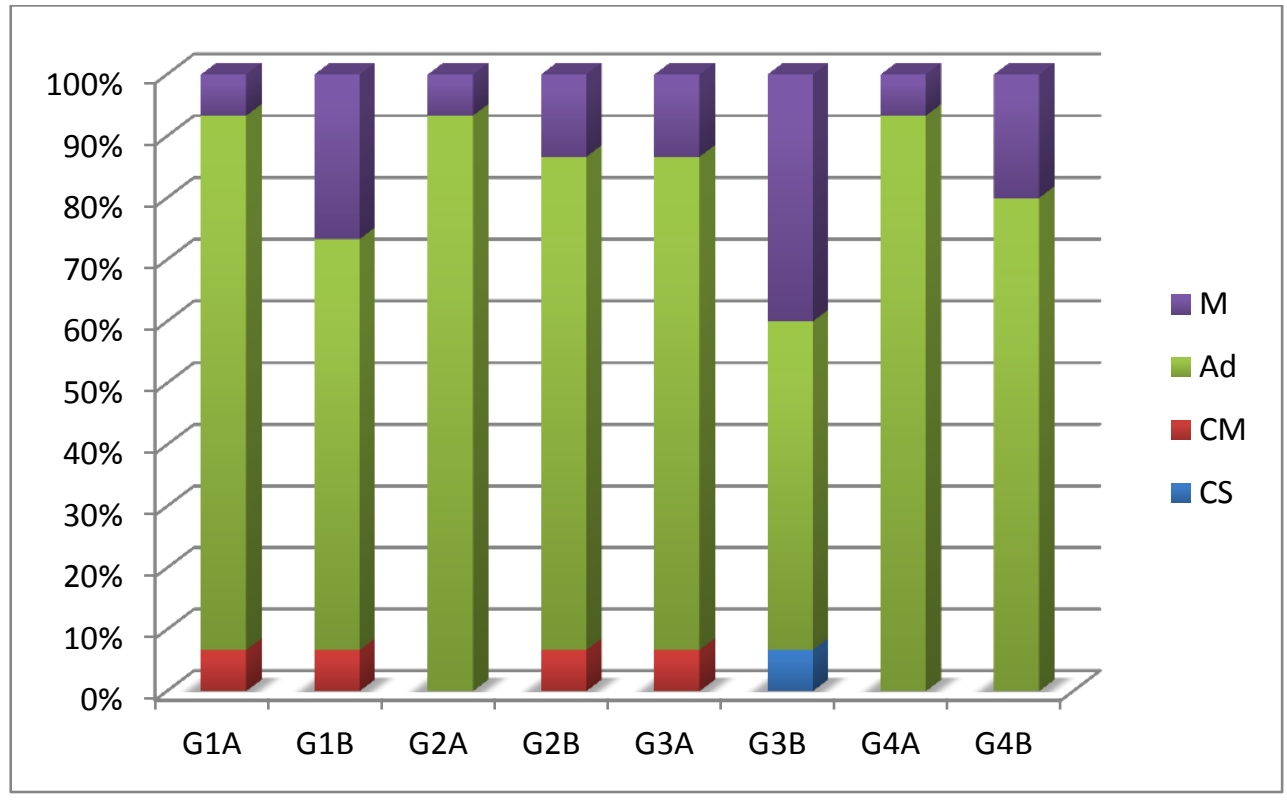

Figura 9. Média dos padrões de fraturas na dentina.

\section{Análise Morfológica Longitudinal da Superfície Dental}

\section{Esmalte}

$\mathrm{Na}$ morfologia superficial do esmalte durante o processo de radiação, pode-se observar que ocorreram alterações principalmente na sua porção orgânica, ou seja, na região interprismática.

Previamente à radiação observou-se que os prismas estavam bem organizados e a porção interprismática bem definida (Figura 10A), sendo essa situação ainda observada após 10Gy e 20Gy (Figura 10B e 10C). Contudo, à dose cumulativa de 30Gy observou-se uma desorganização dos prismas e da camada interprismática (Figura 10D), e em 40Gy ocorreram alterações nas estruturas nos prismas, principalmente nas cabeças prismáticas, e começou-se a observar degradação da região interprismática (Figura 10E). Na dose de 50Gy, notou-se que os prismas perderam sua forma e a região interprismática estava degradada (Figura 10F). Aos 60Gy, os prismas estavam completamente amorfos e a porção interprismática totalmente degradada, tornando difícil sua identificação (Figura 10G e 10H). 

Figura 10. Esmalte (Aumento de 3415x nas figuras de A a G). A: previamente à radiação. B: após 10Gy, observa-se prismas e região interprismática bem organizados. C: após 20Gy verifica-se a mesma disposição inicial. D: após 30Gy, visualiza-se a desorganização de prismas e a degradação da camada interprismática. E: após 40Gy, observam-se alterações nas cabeças dos prismas e a região interprismática se apresenta ainda mais degradada. F: após 50Gy, os prismas apresentam-se amorfos. G: após 60Gy, os prismas estão completamente amorfos e a região interprismática totalmente degradada. H: após 60Gy, os prismas estão completamente amorfos e a região interprismática totalmente degradada (Aumento de 1074x). 


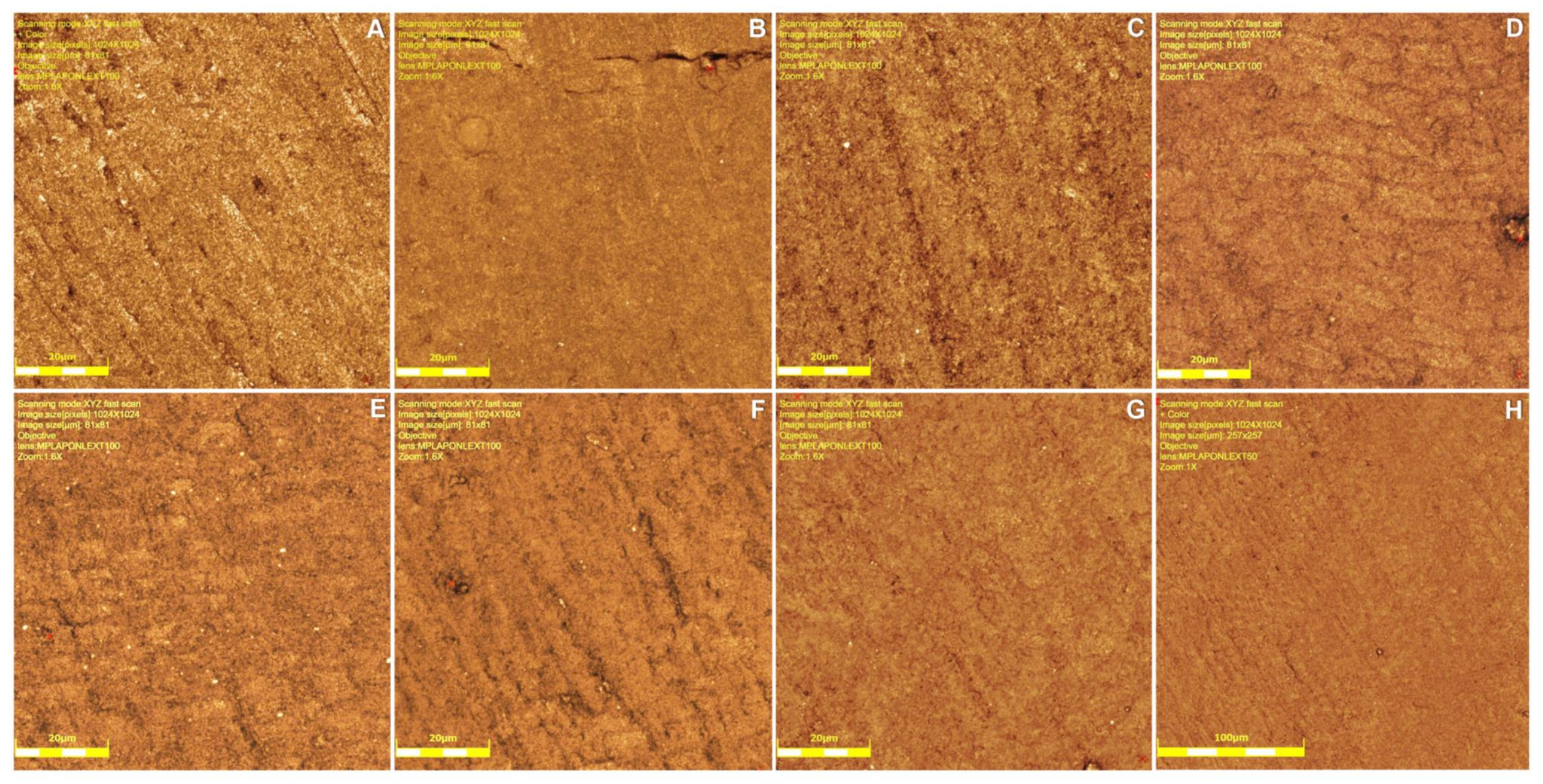



DENTINA

A análise inicial da dentina observou-se que os túbulos dentinários encontravam-se abertos (Figura 11A); após 10Gy estes apresentaram ligeira diminuição de seu diâmetro, sendo mais evidente após 20Gy (Figura 11B e 11C); com 30Gy, os túbulos dentinários apresentavam-se parcialmente obliterados, observando uma ocorrência gradativa a 40Gy e 50Gy (Figura 11D, 11E e 11F); e em 60Gy estes encontravam-se quase completamente obliterados (Figura 11G e 11H). 
Figura 11. Dentina (Aumento de 3415x nas figuras de A a G). A: previamente a radiação. B: após 10Gy, e C: após 20Gy verifica-se ligeira diminuição do diâmetro dos túbulos dentinários. D: após 30Gy, observam-se túbulos parcialmente obliterados. E: após 40Gy, essa obliteração apresenta-se mais evidente F: após 50Gy, túbulos dentinários praticamente obliterados. G: após 60Gy os túbulos encontram-se completamente obliterados. H: após 60 Gy, túbulos completamente obliterados (aumento de 1074x). 


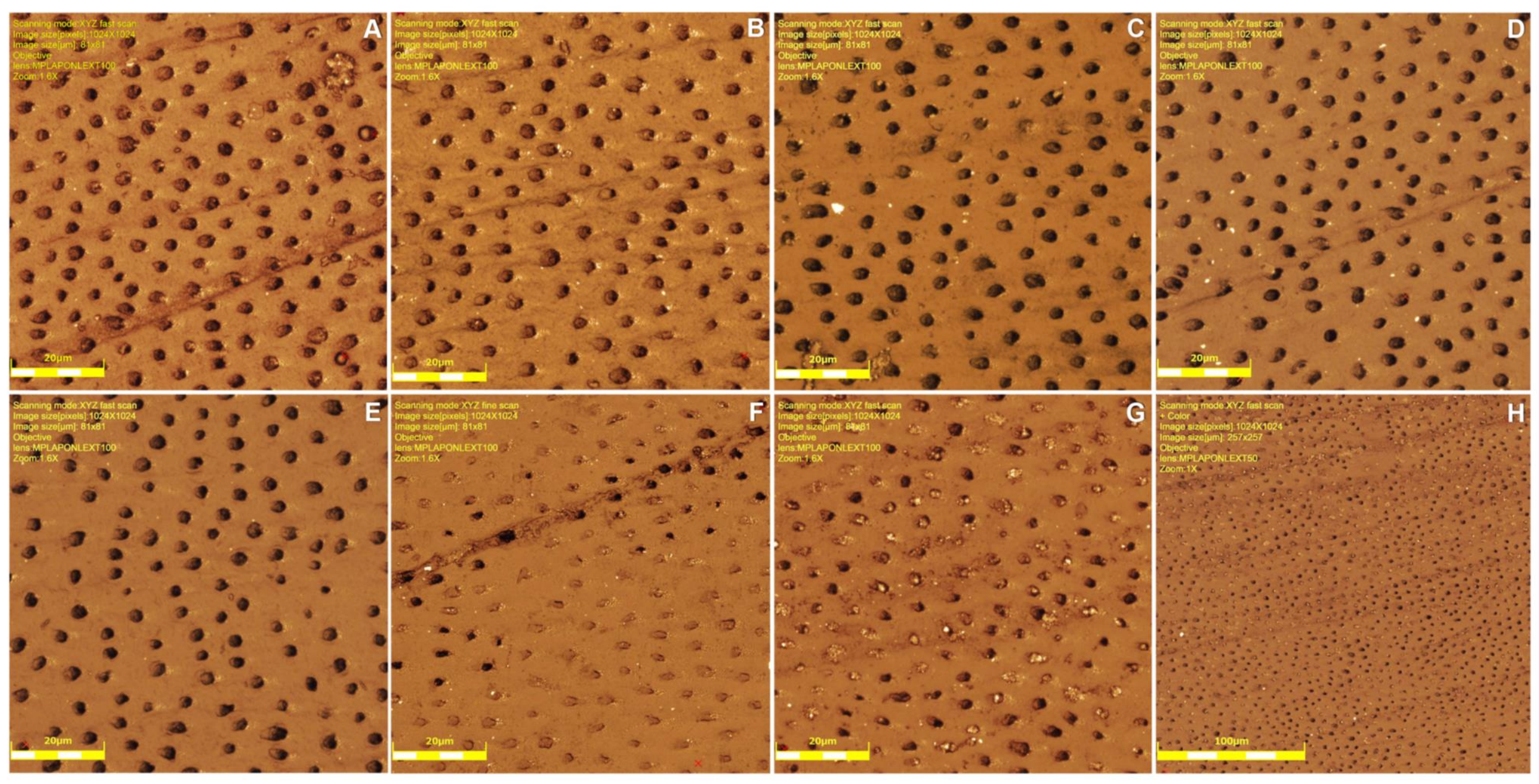





\section{Análise da Interface Adesiva}

Os grupos controle de esmalte apresentaram formação de tags adesivos, sendo que para os grupos do SGB estes tags foram visualmente menores quando comparados ao grupo SGA (Figura 12 A-D). Nos grupos controle de dentina observou-se a formação de tags em ambos os sistemas adesivos, com formação de camada híbrida (Figura 12 E-H). 
Figura 12. Esmalte (grupos controle) A e B: No G1A observa-se formação de tags; C e D: no G1B observa-se formação de tags menos extensos quando comparados ao G1A. Dentina (grupos controle) E e F: no G1A observa-se formação de tags; G e H: no G1B observa-se formação de tags. 

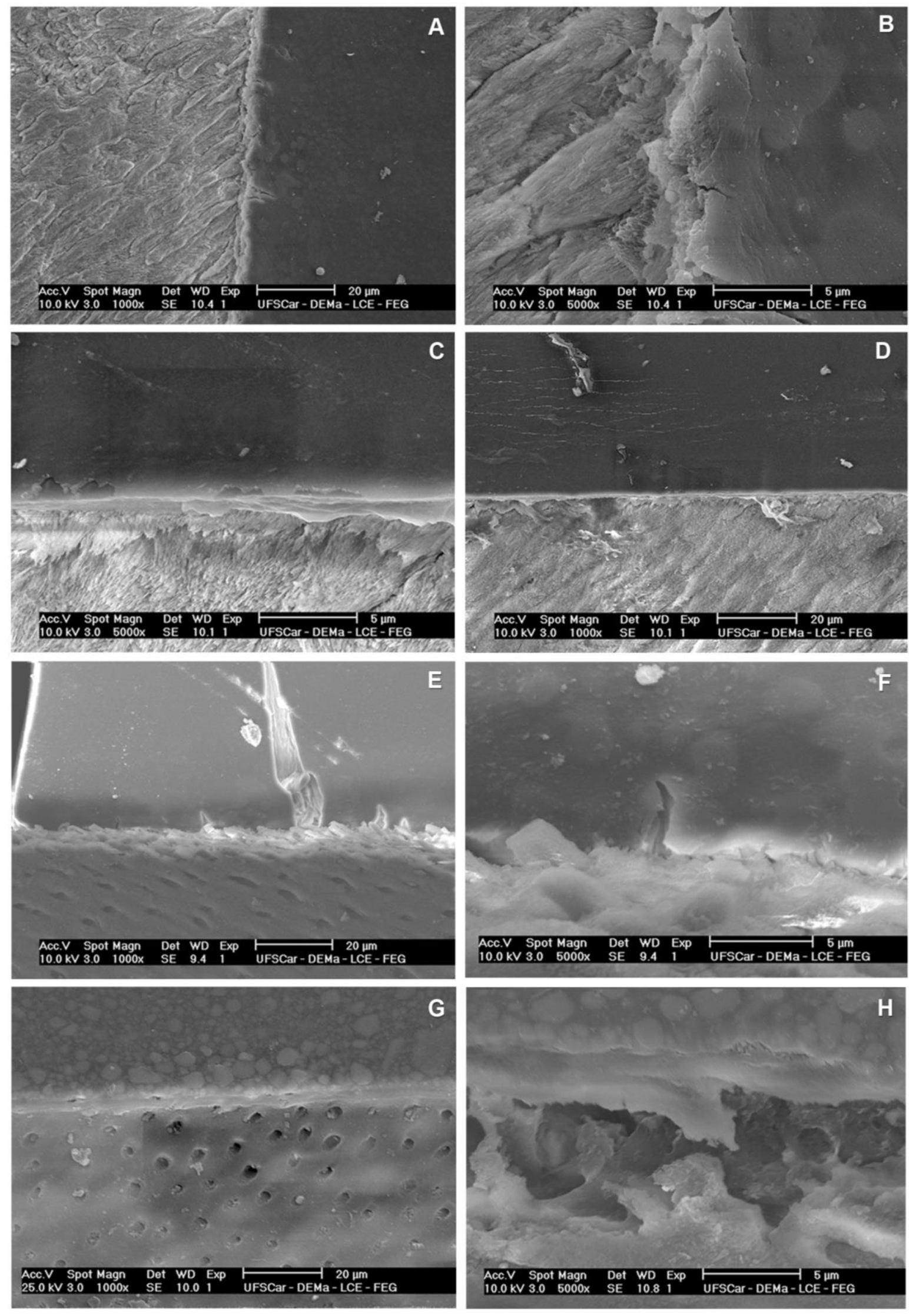

Nos grupos G2 houve perda de corpos de prova dos grupos de esmalte G2A e de dentina G2A e G2B, não sendo possível a realização de MEV nestes corpos visto que as restaurações se soltaram no momento do preparo dos espécimes.

Para o grupo de esmalte G2B observou-se uma alteração tanto no substrato dental quanto na resina e praticamente não houve formação de tags, estando e o adesivo estava sobreposto ao esmalte (Figura 13).

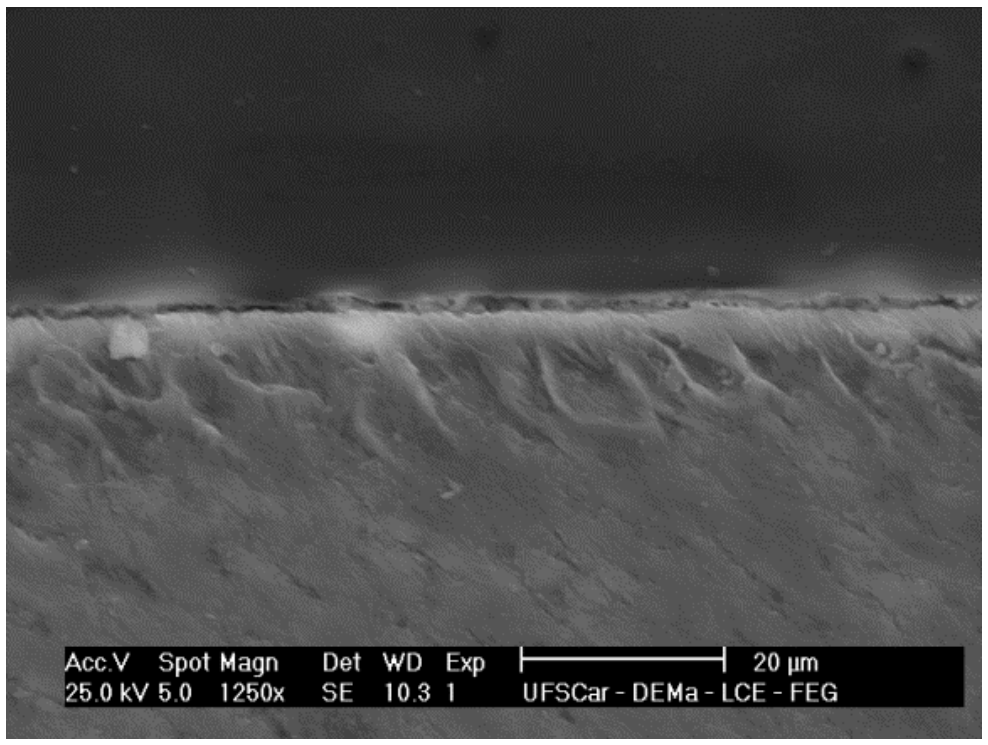

Figura 13. Esmalte (grupo restaurado e irradiado) - Grupo G2B: alteração no substrato dental e na resina, quase não há formação de tags, encontrando-se o adesivo apenas sobreposto ao esmalte.

Nos grupos G3 de esmalte, tanto no G3A quanto no G3B, houve formação de uma camada adesiva mais fina, porém os tags apresentaram-se mais prolongados (Figura $14 \mathrm{~A}$ D). Nos grupos G3 de dentina, tanto no G3A quanto no G3B, houve formação de gaps entre a camada adesiva e o substrato dental com formação de camada híbrida (Figura 14 E-H). 
Figura 14. A, B, C, D: Esmalte (grupos irradiados e depois restaurados) A e B: grupo G3A com formação de fina camada adesiva e tags mais prolongados. C e D: grupo G3B observar-se a formação de fina camada adesiva e tags mais prolongados. E, F, G, H: Dentina (grupos irradiados e depois restaurados) E e F: grupo G3A, observa-se formação de gaps entre a camada adesiva e o substrato dental. G e H: grupo G3B formação de gaps entre a camada adesiva e a dentina dental. 

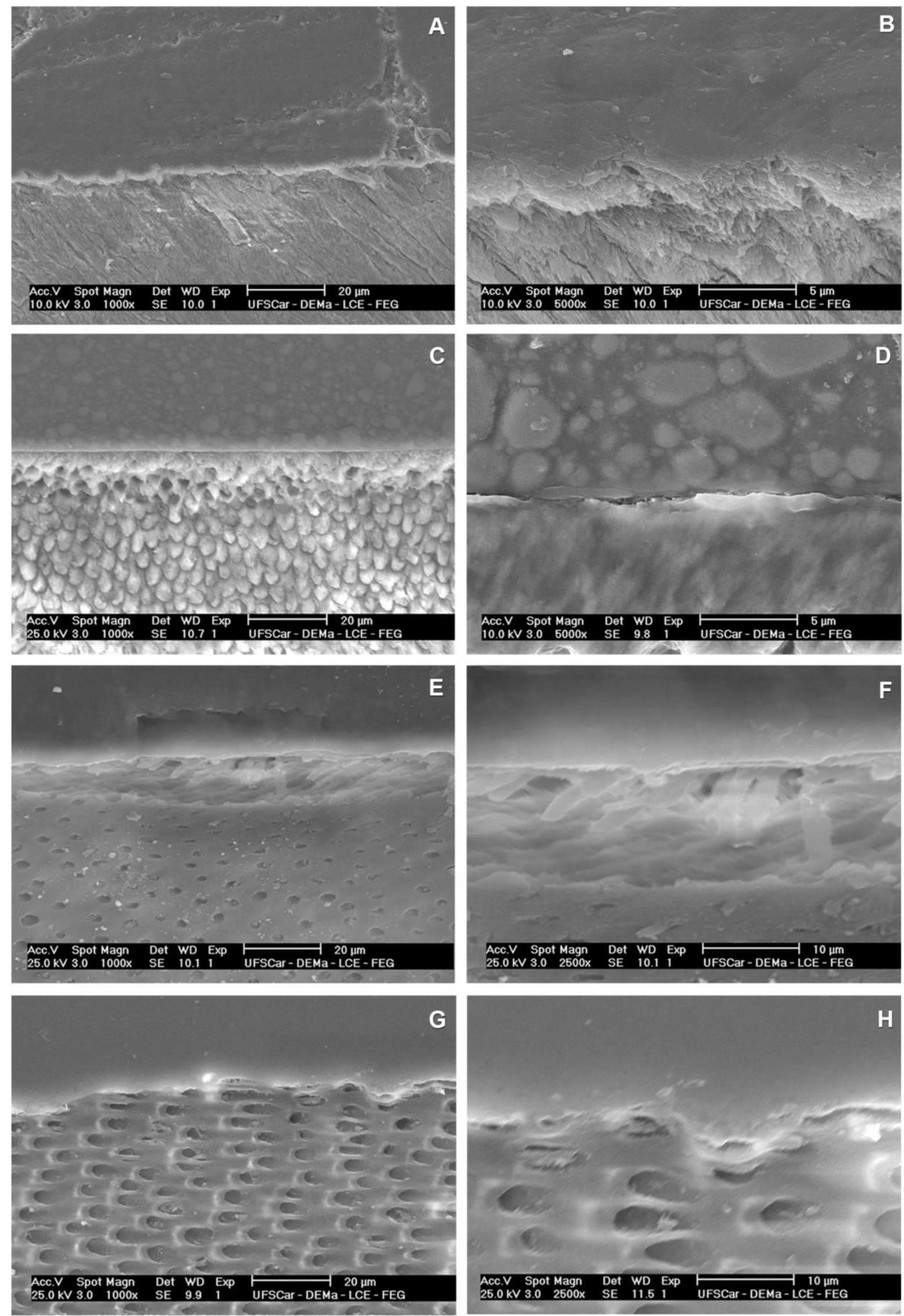

5. Discussão 



\section{DIscuSSÃo}

O câncer de cabeça e pescoço é frequente, sendo estimado que morreram em 2008 mais de 128.000 pessoas devido à ao câncer na cavidade bucal (Jemal et al., 2011) . Indivíduos diagnosticados com esse tipo de câncer podem ser tratados por meio de cirurgia, quimioterapia e/ou radioterapia (Kim, Hong e Khuri, 2002; Qing et al., 2015). Esta última amplamente utilizada, por se apresentar muito eficiente, seja como terapia primária ou coadjuvante (Adelstein, 2003; Soares et al., 2011).

Embora muito eficiente, a radioterapia pode ocasionar muitos efeitos colaterais, entre eles a "cárie de radiação" (Kielbassa et al., 2006; Silva et al., 2009; Beech et al., 2014), que atualmente é designada como a desintegração dos tecidos dentais mineralizados após radioterapia de tumores na região de cabeça e pescoço, constituindo-se é um dos principais efeitos colaterais observados em pacientes submetidos a este tipo de terapia (Lieshout e Bots, 2014). Estudos prévios de Gernhardt, (2001) e Kielbassa et al. (2006) observaram que este tipo de desintegração dos tecidos dentais mineralizados era resultado, principalmente, da xerostomia resultante dos danos às glândulas salivares ocasionados pela radioterapia. Atualmente sabe-se que são ocasionadas não somente pela xerostomia, mas também pelos efeitos diretos da radiação sobre os tecidos dentais mineralizados, os quais sofrem mudanças significativas na sua estrutura, que culminam com uma redução dramática das propriedades biomecânicas (Soares et al., 2010; Goncalves et al., 2014; Lieshout e Bots, 2014). Juntamente a estes fatores, uma higiene bucal inadequada e o consumo de uma dieta rica em carboidratos e alimentos mais pastosos, pós tratamento radioterápico, podem ser agravantes para este tipo de lesão de cárie (Lieshout e Bots, 2014).

Até a década passada acreditava-se que o álcool e o tabaco eram os principais fatores de risco para o desenvolvimento de câncer na região de cabeça e pescoço (Hashibe et al., 2007; Boffetta et al., 2008; Hashibe et al., 2009; Secretan et al., 2009; Lassen, 2013), o que caracterizava sua maior prevalência em homens em relação a mulheres, visto que estes, geralmente, fazem maior consumo de tais produtos (INCA 2014; Rettig e Dsouza, 2015). Porém esta característica da população vem mudando, e desde a década passada o 
HPV vem sendo reconhecido como causa primária do câncer de cabeça e pescoço (Smith et al., 2004; Lothaire et al., 2006; Pintos et al., 2008; Jemal et al., 2011; Lassen, 2013; Rettig e D'souza, 2015). Ainda os pacientes que desenvolvem câncer nesta região devido ao HPV além de mais novos, nem sempre fazem uso de álcool e tabaco (Chaturvedi et al., 2008; Gillison et al., 2008; Gillison et al., 2012; Lassen, 2013; Young et al., 2015) e apresentam prognóstico mais favorável, quando comparados a indivíduos que desenvolveram este tipo de câncer devido a outros fatores (Ang et al., 2010; Lassen, 2013; Young et al., 2015).

A maioria dos estudos existentes analisaram a alteração da estrutura dental após irradiação por cobalto 60 (Jansma et al., 1988; Pioch, Golfels e Staehle, 1992; Al-Nawas et al., 2000; Soares et al., 2010; Soares et al., 2011; De Siqueira Mellara et al., 2014; Goncalves et al., 2014). Contudo optou-se neste estudo pelo acelerador linear por ser atualmente o aparelho mais moderno e preciso para a radioterapia empregado para 0 tratamento de pacientes com estes tipos de tumores. Ressalta-se que o acelerador linear já foi empregado em estudos recentes como o de Martins et al. (2015) e de Santin et al. (2015). Por meio dessa tecnologia é possível irradiar tecidos ou órgãos neoplásicos com precisão (tanto na localização quanto na intensidade do feixe) de forma que os tecidos sadios em sua volta possam ser preservados. Na teleterapia por cobalto, o ponto de máxima absorção está a aproximadamente $5 \mathrm{~mm}$ de profundidade (penetração). Com o uso dos aceleradores lineares de alta energia, esse ponto pode chegar até $30 \mathrm{~mm}$ de profundidade (Santin et al., 2015).

As doses para tratamento de câncer variam de 50 a 70Gy, dependendo do tumor e da rotina hospitalar aplicada. A dose comum de irradiação para o tratamento de carcinomas espinocelulares de cabeça e pescoço costuma variar entre 60 e 70Gy. A dose diária é normalmente 2Gy/dia, 5 dias/semana, intercalada por 2 dias sem radiação, correspondente aos finais de semana, a fim de que os tecidos sadios adjacentes ao tumor possam se recuperar (Huber e Terezhalmy, 2003); Vissink et al., 2003; Kielbassa et al., 2006). Neste estudo, a fim de simular as condições clínicas de tratamento de tumores da região de cabeça e pescoço, utilizou-se dose total de 60Gy (conforme dose padrão utilizada no 
HCRP/USP), com dose-fração incremental de 2Gy/dia durante seis semanas, respeitando dois dias de intervalo (Anneroth, Holm e Karlsson, 1985; Jansma et al., 1988; Jham e Da Silva Freire, 2006; Otmani, 2007; De Siqueira Mellara et al., 2014; Goncalves et al., 2014; Martins et al., 2015; Santin et al., 2015). Além disso, este protocolo foi previamente utilizado na literatura em estudos que avaliaram alterações in vitro, (Jansma et al., 1988; Pioch, Golfels e Staehle, 1992; Kielbassa et al., 1997; Al-Nawas et al., 2000; Bulucu et al., 2009; Soares et al., 2010; Soares et al., 2011; De Siqueira Mellara et al., 2014; Goncalves et al., 2014; Martins et al., 2015; Santin et al., 2015), in situ (Kielbassa et al., 1999; Al-Nawas et al., 2000; Kielbassa, 2000) e in vivo (Al-Nawas et al., 2000) das estruturas dentais.

Considerando os efeitos deletérios da radiação ionizante sobre as estruturas dentais, possivelmente em função da alteração nas propriedades mecânicas dos mesmos (Grotz et al., 1997; Soares et al., 2010; Goncalves et al., 2014), neste estudo optou-se pela utilização do teste de cisalhamento para avaliação da resistência de união dos sistemas adesivos ao substrato dental ao invés do teste de microtração, em virtude do risco de tais alterações poderem levar a quebras do substrato dental e a perda de corpos de prova que poderia comprometer a viabilidade do estudo.

A desintegração dos tecidos dentais mineralizados após radioterapia de tumores na região de cabeça e pescoço apresenta características singulares tais como: ocorrer logo após o tratamento, progredir rapidamente e acometer especialmente a porção cervical (Kielbassa et al., 2006; Gernhardt, 2001 Lieshout e Bots, 2014). Sendo necessário, nestes casos, a intervenção odontológica, por meio de procedimentos restauradores. De acordo com (Mccomb et al., 2002) as resinas compostas em associação com os sistemas adesivos são os materiais mais indicados para pacientes submetidos à radioterapia na região de cabeça e pescoço. Portanto, neste estudo, optou-se por testar os adesivos Adper ${ }^{\mathrm{TM}}$ Single Bond 2 e Clearfil SE Bond, visto que estes são amplamente utilizados na conduta clínica para realização de procedimentos restauradores, sendo este último considerado o padrão ouro dentre os adesivos self-etch de dois passos (De Munck, Van Landuyt, et al., 2005; Van Landuyt et al., 2009; Peumans et al., 2010; Van Landuyt et al., 2010). 
No presente estudo observou-se que o Clearfill SE Bond apresentou melhores resultados quando comparado ao Adper ${ }^{\mathrm{TM}}$ Single Bond 2 no substrato esmalte. (Buonocore, 1955)Buonocore (1955) propôs que ácidos deveriam ser utilizados na superfície do esmalte para que houvesse a formação de microporosidades e o substrato se tornasse mais receptivo a penetração e embricamento mecânico dos sistemas adesivos, pela alteração da energia livre de superfície aumentando-a. O esmalte dental após ser irradiado torna-se mais poroso como observado na análise morfológica por meio de miscroscopia confocal deste estudo, o que poderia justificar a melhor adesão do Clearfill SE Bond ao substrato dental irradiado. Este fato pode ser devido tanto a uma alteração de energia de superfície do esmalte pela radiação ionizante a qual pode favorecer a penetração do sistema adesivo (Santin et al., 2015), quanto à ausência de necessidade de condicionamento ácido deste sistema adesivo, o qual sobre uma estrutura já porosa poderia atuar como um sobre condicionamento.

Com relação ao fator tempo de restauração no esmalte observou-se que a restauração realizada previamente a radiação apresntou pior comportamento em relação aos demais tempos. Provavelmente este fato ocorreu devido as alterações sofridas no binômio substrato dental/sistema adesivo durante a radiação, que também pode ter afetado a integridade da interface adesiva. A maior porosidade do esmalte pós radiação poderia justificar os maiores valores de adesão no grupo irradiado e restaurado. Divergindo com Naves et al., 2012, que observaram que a resistência adesiva foi superior no grupo restaurado antes de irradiar.

No grupo irradiado e depois restaurado houve formação de uma camada adesiva mais fina comparado com os demais grupos, porém os tags apresentaram-se mais prolongados. A possível explicação para este fato pode ser a alteração da morfologia do substrato dental após a radiação, visto que a porção interprismática do esmalte exposto a radiação torna-se mais evidente, o que foi visto por Gonçalves et al. (2014), possibilitando a maior permeabilidade do adesivo. 
Na comparação entre os sistemas adesivos, observou-se que o Clearfil SE Bond apresentou resistência adesiva ao cisalhamento superior quando comparado ao Adper Single Bond 2. A diferença de comportamento dos diferentes sistemas adesivos ao esmalte após a radioterapia poderia ser justificada pelo fato da radioterapia promover alterações na superfície do esmalte, talvez tornando-o mais poroso, e degradando sua porção inorgânica como observado pelo presente estudo por meio de microscopia confocal e por Gonçalves et al. (2014) por meio de MEV. Acreditamos que essas alterações possam favorecer a melhor adesão de sistemas adesivos do tipo self-etch onde o primer desmineraliza parcialmente o substrato, sem modifica-lo substancialmente e incorporando a smear layer que possui uma espessura média de 1 a $3 \mu \mathrm{m}$ (Pashley et al., 1988). Pode-se observar que as alterações ocasionadas pela radioterapia no esmalte dental sejam favoráveis para a melhor adesão dos sistemas self-etch, entretanto, a escassez de outros estudos na literatura específica acerca da avaliação das restaurações em esmalte de dentes permanentes, antes e após a irradiação, não permite uma comparação direta dos resultados obtidos nesse estudo.

No presente estudo foi observado o predomínio de fratura adesiva em todos os grupos, concordando parcialmente com os resultados de Naves et al. (2012), que demonstraram predomínio de fraturas adesivas nos grupos controle e restaurado após irradiação, entretanto Naves et al. (2012) observaram prevalência de fratura coesiva ao substrato no grupo irradiado e depois restaurado, o que difere dos resultados obtidos no presente estudo.

Quando realizada análise da morfologia da superfície do esmalte, por meio de microscopia confocal, foi possível observar alterações principalmente na sua porção orgânica, ou seja, na região interprismática. Embora o conteúdo orgânico do esmalte corresponda a menos de $1 \%$ de seu volume, alterações deste conteúdo podem afetar as propriedades mecânicas do substrato (Jameson, Hood e Tidmarsh, 1993; Spears, 1997; White et al., 2001; Baldassarri, Margolis e Beniash, 2008). Houve um aumento crescente das alterações na superfície de esmalte a partir da dose acumulativa de 30Gy, e após 60Gy, os prismas encontravam-se completamente amorfos e a porção interprismática totalmente 
degradada, tornando difícil sua identificação. Os resultados do presente estudo corroboram com os de Gonçalves et al. (2014) que verificaram por meio da MEV que a irradiação ocasionou alterações no esmalte, conforme o aumento cumulativo da dose de radiação, com degradação da camada interprismática.

Segundo os resultados do presente estudo foi possível perceber que houve alteração da interface adesiva nos diferentes grupos, sendo possível observar, por meio de MEV, que nos grupos controle do esmalte houve formação de tags, no grupo restaurado e irradiado os tags quase não foram formados e no grupo irradiado e depois restaurado, embora a camada adesiva formada tenha sido mais fina, houve formação de tags mais prolongados, o que pode ser explicado pelo aumento da porosidade da superfície a qual já foi previamente observada por Gonçalves et al. (2014), e novamente verificada na análise morfológica longitudinal por meio de microscopia confocal neste estudo, permitindo a melhor penetração do sistema adesivo. Como na literatura não existem estudos que já tenham realizado a avaliação da interface adesiva em esmalte irradiado, não é possível uma comparação direta dos nossos resultados.

Já quando avaliado o fator sistema adesivo na dentina, o grupo SGB apresentou maior média de resistência adesiva quando comparado ao SB, indo de acordo com afirmações já previamentes descritas na literatura de que sistemas adesivos self-etch, de pelo menos dois passos, apresentam resultados mais favoráveis para a dentina (Frankenberger et al., 2007). Isto pode ser justificado pelo fato da adesão à dentina ser mais complexa e imprevisível quando comparada à adesão ao esmalte, em função de sua estrutura tubular e de sua umidade intrínseca, e os sistemas adesivos do tipo self-etch, por utilizarem-se de ácidos hidrofílicos como monômeros que desmineralizam e penetram na dentina simultaneamente evitam a penetração parcial de adesivo em áreas previamente desmineralizdas (Nakabayashi e Saimi, 1996; Bulucu et al., 2009). Ainda os sistemas adesivos autocondicionantes aumentam simultaneamente a permeabilidade dentinária, pela acidez intrínseca, e facilitam a penetraçao dos monômeros resinosos nas microporosidades 
produzidas na dentina (Pashley e Carvalho, 1997), justificando a melhor adesão do grupo CL na dentina irradiada.

Como observado, o comportamento dos sistemas adesivos foi mantido, onde o SGB mostrou-se superior ao SGA no quesito adesão à dentina, deve-se provavelmente ao fato dos sistemas self-etch, não utilizarem-se de ácidos e visto que seu primer tem $\mathrm{pH}$ 2,0, ocasionando a desmineralização parcial da dentina, ocorrendo a formação de uma camada híbrida uniforme, de 0,5 a $1 \mu \mathrm{m}$, com hidroxiapatita substancial que protege as fibras colágenas (Van Meerbeek et al., 2003; De Munck, Van Landuyt, et al., 2005; Van Landuyt et al., 2006; Bulucu et al., 2009; Peumans et al., 2010), também já foi comprovado que o 10Metacriloiloxidecil dihidrogênio fosfato, presente no primer do CL, interage com a hidroxiapatita residual, por meio de ligações iônicas primárias (Yoshida et al., 2004). Já os sistemas adesivos etch and rinse desmineralizam completamentamente a dentina, expondo assim mais colágeno deixando os cristais de hidroxiapatita sem proteção.

No presente estudo pode-se observar que no fator tempo de restauração não houve diferença quanto a resistência de união entre os grupos restaurado e irradiado e irradiado e restaurado, apresentando estes grupos as menores médias. Os mesmos resultados foram observados por (Biscaro et al., 2009) e Naves et al. (2012), os quais demonstraram redução na resistência de união de restaurações realizadas na superfície da dentina submetida ao tratamento radioterápico. Entretanto, discordam dos resultados obtidos por Gernhardt et al. (2001), onde não houve diferença entre os valores de resistência a união na superfície dentinária restaurada pós radiação e não irradiada. A redução nos valores de resistência de união nos grupos irradiados pode ser resultante de alterações induzidas no substrato dental pela radiação, conforme demonstrado em estudos prévios, os quais apontaram redução nas propriedades mecânicas e danos nas fibrilas colágenas da dentina (Davis, 1975; Kielbassa et al., 1997; Franzel et al., 2006).

De acordo com Pioch et al. (1992); Gernhardt et al. (2001); Soares et al. (2011) e Gonçalves et al. (2014) a radiação pode causar danos especialmente na matriz orgânica dentinária. No entanto, os grupos controle, irradiado e depois restaurado e restaurado após 
6 meses, apresentaram resultados semelhantes entre si, com relação a média de resistência adesiva. Nossos resultados assemelham-se aos de Galleti et al. (2013), onde não foi verificada alteração de comportamento entres os grupos irradiados e não irradiados quando utilizado os mesmo sistemas adesivos empregados no presente estudo.

Quando avaliada a resistência adesiva ao cisalhamento dos diferentes sistemas adesivos, nos diferentes momentos de restauração em dentina, verificou-se que o SGB apresentou resultados superiores ao SGA nos grupos irradiados e restaurado e restaurados após 6 meses, demonstrando mais uma vez a superioridade dos sistemas adesivos self-etch nos dentes pós radiação, diferente dos resultados obtidos por Galleti et al. (2013) onde não houve diferença entre os sistemas adesivos nos grupos irradiados e não irradiados. Possíveis hipóteses para justificar os maiores valores de adesão no grupo restaurado após 6 meses com Clearfil SE Bond seria a forma com que ocorre a adesão nos sistemas selfetch (Pashley e Carvalho, 1997) e talvez pelo poder de remineralização da solução de saliva artificial, que possui em sua formulação componentes tais como fosfato diácido de potássio, fosfato dibásico de potássio, cloreto de potássio, cloreto de sódio, cloreto de magnésio, cloreto de cálcio, fluoreto de sódio, sorbitol 70\%, aromatizante, conservantes (nipagin/nipasol), espessante e água.

Quanto ao padrão de fratura, a exemplo dos espécimes de esmalte, o padrão predominante em todos os grupo na dentina foi a fratura adesiva, concordando com os resultados de Naves et al. (2012) e Galletti et al. (2013).

Sabendo que a radiação age sobre os tecidos orgânicos, e que a dentina madura é composta por aproximadamente $70 \%$ de material inorgânico, $20 \%$ de material orgânico e $10 \%$ de água, adsorvida na superfície do mineral ou nos interstícios entre os cristais, era esperado que este tecido sofresse alterações devido à radiação. Enquanto o componente inorgânico dentinário consiste de hidroxiapatita na forma de pequenas lâminas, o orgânico consiste em $90 \%$ de colágeno (Ten-Cate et al., 2008). Assim, a progressiva obliteração dos túbulos dentinários observada nos dentes irradiados no presente estudo, por meio de microscopia confocal, demonstra claramente a capacidade da radiação afetar a porção 
orgânica dentinária, assim como foi observado no estudo de Gonçalves et al. (2014) que observaram por meio de MEV a obliteração e fissuras na estrutura dentinária e fragmentação das redes de fibras de colágeno. Isso pode ser justificado pela obliteração dos túbulos dentinários ser resultado de um dano celular causado diretamente pelos efeitos radiogênicos como afirmaram Grotz et al. (1997) em seu estudo.

Alterações adicionais à porção orgânica do tecido dentinário pós radiação foram observadas por meio de MEV por Soares et al. (2010) e Gonçalves et al. (2014), que verificaram a degradação e fragmentação progressiva da rede de fibras colágenas e alterações na dentina como um todo conforme o aumento das doses de radiação, sendo estes resultados semelhantes aos do presente estudo por meio de microscopia confocal a laser. (Grotz et al., 1997) atribuíram a degeneração dos processos odontoblásticos, ao dano direto da radiação sobre as células, levando à redução do metabolismo celular, especialmente na área terminal dos odontoblastos. Como no presente estudo, foram utilizados terceiros molares extraídos, portanto sem atividade odontoblástica, uma hipóteses para a desorganização do tecido dentinário é que esta tenha sido oriunda da fragmentação da rede de fibras colágenas.

Quando comparadas as imagens de MEV para análise da interface adesiva podese perceber que no grupo controle de dentina houve formação de tags em ambos os sistemas adesivos, já nos grupos irradiados e depois restaurados foi possível observar a formação de gaps entre a camada adesiva e o substrato. Este achado pode ser resultado da obliteração dos túbulos dentinários pós radiação, como pôde ser observado neste estudo por meio da análise morfológica longitudinal da superfície dentinária e pelo estudo de Gonçalves et al. (2014), por meio de MEV. Devido à ausência de estudos que avaliaram a interface adesiva após radiação não foi possível uma comparação direta dos resultados obtidos no presente estudo.

É claro que este é um estudo in vitro com todas as suas limitações, entretanto, devido a escassez de estudos nessa área, acreditamos que o mesmo possa contribuir para elucidação tanto do processo de desintegração dos tecidos dentais mineralizados pós 
radiação, quanto da escolha do material restaurador mais adequado e do melhor momento para realizar restaurações definitivas em pacientes em tratamento radioterápico. Com base em nossos resultados acreditamos que deva ser escolhido um adesivo dentinário do tipo self-etch, e que o melhor momento para se realizar a restauração em esmalte e/ou dentina seja preferencialmente 6 meses após o tratamento radioterápico. Ainda, vale enfatizar a necessidade de mais estudos nessa área, e uma vez que é de fundamental importância a remoção de focos infecciosos da cavidade bucal previamente à radioterapia, o que inclui a remoção de lesões de cárie, e tendo sido observado também que o comportamento de restaurações adesivas previamente à radioterapia foi insatisfatório, sugerimos que futuros estudos avaliando o comportamento de materiais como cimento de ionômero de vidro sejam realizados. 
6. Conclusões 



\section{CONCLUSÕES}

Com base nos resultados deste estudo e considerando as limitações inerentes aos modelos experimentais utilizados, conclui-se que:

- Os diferentes sistemas adesivos apresentaram comportamentos distintos na resistência de união em ambos os substratos, onde o Clearfil SE Bond apresentou desempenho superior ao Adper ${ }^{\mathrm{TM}}$ Single Bond 2.

- No fator tempo de restauração observou-se que a irradiação afetou a adesão nos dentes restaurados e que após 6 meses os efeitos sobre a adesão à dentina foi mínimo.

- Na análise morfológica do esmalte observou-se após a irradiação degradação da porção interprismática e também alteração da forma dos prismas. Na dentina observou-se obliteração dos túbulos dentinários.

- Na análise da interface adesiva observou-se que a irradiação afetou a morfologia da mesma, levando a formação de tags mais prolongados no esmalte e de gaps entre a camada adesiva e a dentina. 

Referências 



\section{REFERÊNCIAS}

ADELSTEIN, D. J. Systemic chemotherapy for squamous cell head and neck cancer. Expert Opin Pharmacother, v. 4, n. 12, p. 2151-63, Dec 2003. ISSN 1465-6566.

AL-NAWAS, B. et al. Using ultrasound transmission velocity to analyse the mechanical properties of teeth after in vitro, in situ, and in vivo irradiation. Clin Oral Investig, v. 4, n. 3, p. 168-72, Sep 2000. ISSN 1432-6981.

ANG, K. K. et al. Human papillomavirus and survival of patients with oropharyngeal cancer. N Engl J Med, v. 363, n. 1, p. 24-35, Jul 1 2010. ISSN 0028-4793.

ANNEROTH, G.; HOLM, L. E.; KARLSSON, G. The effect of radiation on teeth. A clinical, histologic and microradiographic study. Int J Oral Surg, v. 14, n. 3, p. 269-74, Jun 1985. ISSN 0300-9785.

BALDASSARRI, M.; MARGOLIS, H. C.; BENIASH, E. Compositional determinants of mechanical properties of enamel. J Dent Res, v. 87, n. 7, p. 645-9, Jul 2008. ISSN 00220345.

$\mathrm{BEECH}, \mathrm{N}$. et al. Dental management of patients irradiated for head and neck cancer. Aust Dent J, v. 59, n. 1, p. 20-8, Mar 2014. ISSN 0045-0421.

BISCARO, S. L. et al. Effect of X-ray radiation dose on the bond strength of different adhesive systems to dentin. J Adhes Dent, v. 11, n. 5, p. 355-60, Oct 2009. ISSN 14615185.

BLOT, W. J. et al. Smoking and drinking in relation to oral and pharyngeal cancer. Cancer Res, v. 48, n. 11, p. 3282-7, Jun 1 1988. ISSN 0008-5472.

BOFFETTA, P. et al. Smokeless tobacco and cancer. Lancet Oncol, v. 9, n. 7, p. 667-75, Jul 2008. ISSN 1470-2045.

BULUCU, B. et al. Effect of radiotherapy on the microleakage of adhesive systems. $\mathbf{J}$ Adhes Dent, v. 11, n. 4, p. 305-9, Aug 2009. ISSN 1461-5185.

BUONOCORE, M. G. A simple method of increasing the adhesion of acrylic filling materials to enamel surfaces. J Dent Res, v. 34, n. 6, p. 849-53, Dec 1955. ISSN 0022-0345.

CHAACHOUAY, $\mathrm{H}$. et al. Autophagy contributes to resistance of tumor cells to ionizing radiation. Radiother Oncol, v. 99, n. 3, p. 287-92, Jun 2011. ISSN 0167-8140.

CHATURVEDI, A. K. et al. Incidence trends for human papillomavirus-related and -unrelated oral squamous cell carcinomas in the United States. J Clin Oncol, v. 26, n. 4, p. 612-9, Feb 1 2008. ISSN 0732-183x.

DAVIS, W. B. Reduction in dentin wear resistance by irradiation and effects of storage in aqueous media. J Dent Res, v. 54, n. 5, p. 1078-81, Sep-Oct 1975. ISSN 0022-0345.

DE MUNCK, J. et al. A critical review of the durability of adhesion to tooth tissue: methods and results. J Dent Res, v. 84, n. 2, p. 118-32, Feb 2005. ISSN 0022-0345.

One-day bonding effectiveness of new self-etch adhesives to bur-cut enamel and dentin. Oper Dent, v. 30, n. 1, p. 39-49, Jan-Feb 2005. ISSN 0361-7734. 
DE SIQUEIRA MELLARA, T. et al. The effect of radiation therapy on the mechanical and morphological properties of the enamel and dentin of deciduous teeth--an in vitro study. Radiat Oncol, v. 9, p. 30, 2014. ISSN 1748-717x.

DOBROSSY, L. Epidemiology of head and neck cancer: magnitude of the problem. Cancer Metastasis Rev, v. 24, n. 1, p. 9-17, Jan 2005. ISSN 0167-7659.

ERMIS, R. B. et al. Clinical evaluation of a two-step etch\&rinse and a two-step self-etch adhesive system in Class II restorations: two-year results. Oper Dent, v. 34, n. 6, p. 656-63, Nov-Dec 2009. ISSN 0361-7734.

FERLAY, J. et al. Estimates of worldwide burden of cancer in 2008: GLOBOCAN 2008. Int J Cancer, v. 127, n. 12, p. 2893-917, Dec 15 2010. ISSN 0020-7136.

FRANKENBERGER, R. et al. Marginal integrity: is the clinical performance of bonded restorations predictable in vitro? J Adhes Dent, v. 9 Suppl 1, p. 107-16, 2007. ISSN 14615185.

FRANKENBERGER, R.; TAY, F. R. Self-etch vs etch-and-rinse adhesives: effect of thermomechanical fatigue loading on marginal quality of bonded resin composite restorations. Dent Mater, v. 21, n. 5, p. 397-412, May 2005. ISSN 0109-5641.

FRANZEL, W. et al. Effect of tumor therapeutic irradiation on the mechanical properties of teeth tissue. Z Med Phys, v. 16, n. 2, p. 148-54, 2006. ISSN 0939-3889.

GALETTI, R. et al. Radiotherapy does not impair dentin adhesive properties in head and neck cancer patients. Clin Oral Investig, v. 18, n. 7, p. 1771-8, Sep 2014. ISSN 1432-6981.

GAUDET, M. M. et al. Anthropometry and head and neck cancer:a pooled analysis of cohort data. Int J Epidemiol, v. 44, n. 2, p. 673-81, Apr 2015. ISSN 0300-5771.

GERNHARDT, C. R. et al. Tensile bond strengths of four different dentin adhesives on irradiated and non-irradiated human dentin in vitro. J Oral Rehabil, v. 28, n. 9, p. 814-20, Sep 2001. ISSN 0305-182X.

GILLISON, M. L. et al. Human papillomavirus and diseases of the upper airway: head and neck cancer and respiratory papillomatosis. Vaccine, v. 30 Suppl 5, p. F34-54, Nov 202012. ISSN 0264-410x.

Distinct risk factor profiles for human papillomavirus type 16-positive and human papillomavirus type 16-negative head and neck cancers. J Natl Cancer Inst, v. 100, n. 6, p. 407-20, Mar 19 2008. ISSN 0027-8874.

GONCALVES, L. M. et al. Radiation therapy alters microhardness and microstructure of enamel and dentin of permanent human teeth. J Dent, v. 42, n. 8, p. 986-92, Aug 2014. ISSN 0300-5712.

GROTZ, K. A. et al. [New evidence for the etiology of so-called radiation caries. Proof for directed radiogenic damage od the enamel-dentin junction]. Strahlenther Onkol, v. 173, n. 12, p. 668-76, Dec 1997. ISSN 0179-7158.

HASHIBE, M. et al. Alcohol drinking in never users of tobacco, cigarette smoking in never drinkers, and the risk of head and neck cancer: pooled analysis in the International Head and Neck Cancer Epidemiology Consortium. J Natl Cancer Inst, v. 99, n. 10, p. 777-89, May 16 2007. ISSN 0027-8874. 
. Interaction between tobacco and alcohol use and the risk of head and neck cancer: pooled analysis in the International Head and Neck Cancer Epidemiology Consortium. Cancer Epidemiol Biomarkers Prev, v. 18, n. 2, p. 541-50, Feb 2009. ISSN 1055-9965.

HERRERO, R. et al. Human papillomavirus and oral cancer: the International Agency for Research on Cancer multicenter study. J Natl Cancer Inst, v. 95, n. 23, p. 1772-83, Dec 3 2003. ISSN 0027-8874.

$\mathrm{HU}, \mathrm{J} . \mathrm{Y}$. et al. Restoration of teeth with more-viscous glass ionomer cements following radiation-induced caries. Int Dent J, v. 52, n. 6, p. 445-8, Dec 2002. ISSN 0020-6539.

HUBER, M. A.; TEREZHALMY, G. T. The head and neck radiation oncology patient. Quintessence Int, v. 34, n. 9, p. 693-717, Oct 2003. ISSN 0033-6572.

JAMESON, M. W.; HOOD, J. A.; TIDMARSH, B. G. The effects of dehydration and rehydration on some mechanical properties of human dentine. J Biomech, v. 26, n. 9, p. 1055-65, Sep 1993. ISSN 0021-9290.

JANSMA, J. et al. The effect of X-ray irradiation on the demineralization of bovine dental enamel. A constant composition study. Caries Res, v. 22, n. 4, p. 199-203, 1988. ISSN 0008-6568.

JEMAL, A. et al. Global cancer statistics. CA Cancer J Clin, v. 61, n. 2, p. 69-90, Mar-Apr 2011. ISSN 0007-9235.

JHAM, B. C.; DA SILVA FREIRE, A. R. Oral complications of radiotherapy in the head and neck. Braz J Otorhinolaryngol, v. 72, n. 5, p. 704-8, Sep-Oct 2006. ISSN 1808-8694 (Print) 1808-8686.

JOSHI, V. K. Dental treatment planning and management for the mouth cancer patient. Oral Oncol, v. 46, n. 6, p. 475-9, Jun 2010. ISSN 1368-8375.

KANCA, J., 3RD. Resin bonding to wet substrate. 1. Bonding to dentin. Quintessence Int, v. 23, n. 1, p. 39-41, Jan 1992. ISSN 0033-6572.

KIELBASSA, A. M. In situ induced demineralization in irradiated and non-irradiated human dentin. Eur J Oral Sci, v. 108, n. 3, p. 214-21, Jun 2000. ISSN 0909-8836.

KIELBASSA, A. M. et al. Irradiation effects on microhardness of fluoridated and nonfluoridated bovine dentin. Eur J Oral Sci, v. 105, n. 5 Pt 1, p. 444-7, Oct 1997. ISSN 09098836.

Radiation-related damage to dentition. Lancet Oncol, v. 7, n. 4, p. 326-35, Apr 2006. ISSN 1470-2045.

Correlation of transversal microradiography and microhardness on in situ-induced demineralization in irradiated and nonirradiated human dental enamel. Arch Oral Biol, v. 44, n. 3, p. 243-51, Mar 1999. ISSN 0003-9969.

KIM, E. S.; HONG, W. K.; KHURI, F. R. Chemoprevention of aerodigestive tract cancers. Annu Rev Med, v. 53, p. 223-43, 2002. ISSN 0066-4219.

LASSEN, P. Current role of human papillomavirus in head and neck oncology. EJC Suppl, v. 11 , n. 2, p. 260-1, Sep 2013. ISSN 1359-6349. 
LEMAIRE, F. et al. Differential expression profiling of head and neck squamous cell carcinoma (HNSCC). Br J Cancer, v. 89, n. 10, p. 1940-9, Nov 17 2003. ISSN 0007-0920.

LIESHOUT, H. F.; BOTS, C. P. The effect of radiotherapy on dental hard tissue--a systematic review. Clin Oral Investig, v. 18, n. 1, p. 17-24, Jan 2014. ISSN 1432-6981.

LOTHAIRE, P. et al. Molecular markers of head and neck squamous cell carcinoma: promising signs in need of prospective evaluation. Head Neck, v. 28, n. 3, p. 256-69, Mar 2006. ISSN 1043-3074.

MARKITZIU, A. et al. In vitro irradiation effects on hardness and solubility of human enamel and dentin pretreated with fluoride. Clin Prev Dent, v. 8, n. 4, p. 4-7, Jul-Aug 1986. ISSN 0163-9633.

MARTINS, C. V. et al. Influence of therapeutic cancer radiation on the bond strength of an epoxy- or an MTA-based sealer to root dentine. Int Endod J, Oct 1 2015. ISSN 0143-2885.

MCCOMB, D. et al. A clinical comparison of glass ionomer, resin-modified glass ionomer and resin composite restorations in the treatment of cervical caries in xerostomic head and neck radiation patients. Oper Dent, v. 27, n. 5, p. 430-7, Sep-Oct 2002. ISSN 0361-7734.

MENVIELLE, G. et al. Smoking, alcohol drinking and cancer risk for various sites of the larynx and hypopharynx. A case-control study in France. Eur J Cancer Prev, v. 13, n. 3, p. 165-72, Jun 2004. ISSN 0959-8278.

NAKABAYASHI, N.; KOJIMA, K.; MASUHARA, E. The promotion of adhesion by the infiltration of monomers into tooth substrates. J Biomed Mater Res, v. 16, n. 3, p. 265-73, May 1982. ISSN 0021-9304.

NAKABAYASHI, N.; PASHLEY, D. H. Hibridização dos tecidos dentais duros. Quintessence Publishing Co, Ltd, 2000.

NAKABAYASHI, N.; SAIMI, Y. Bonding to intact dentin. J Dent Res, v. 75, n. 9, p. 1706-15, Sep 1996. ISSN 0022-0345.

NAVES, L. Z. et al. Effect of gamma radiation on bonding to human enamel and dentin. Support Care Cancer, v. 20, n. 11, p. 2873-8, Nov 2012. ISSN 0941-4355.

OTMANI, N. Oral and maxillofacial side effects of radiation therapy on children. $\mathbf{J}$ Can Dent Assoc, v. 73, n. 3, p. 257-61, Apr 2007. ISSN 0709-8936.

OVERMAN, V. P. The Oral Cancer Foundation. Int J Dent Hyg, v. 7, n. 3, p. 229-30, Aug 2009. ISSN 1601-5029.

PASHLEY, D. H.; CARVALHO, R. M. Dentine permeability and dentine adhesion. J Dent, v. 25, n. 5, p. 355-72, Sep 1997. ISSN 0300-5712.

PASHLEY, D. H. et al. Scanning electron microscopy of the substructure of smear layers in human dentine. Arch Oral Biol, v. 33, n. 4, p. 265-70, 1988. ISSN 0003-9969.

State of the art etch-and-rinse adhesives. Dent Mater, v. 27, n. 1, p. 1-16, Jan 2011. ISSN 0109-5641. 
PEUMANS, M. et al. Eight-year clinical evaluation of a 2-step self-etch adhesive with and without selective enamel etching. Dent Mater, v. 26, n. 12, p. 1176-84, Dec 2010. ISSN 0109-5641.

PINTOS, J. et al. Human papillomavirus infection and oral cancer: a case-control study in Montreal, Canada. Oral Oncol, v. 44, n. 3, p. 242-50, Mar 2008. ISSN 1368-8375.

PIOCH, T.; GOLFELS, D.; STAEHLE, H. J. An experimental study of the stability of irradiated teeth in the region of the dentinoenamel junction. Endod Dent Traumatol, v. 8, n. 6, p. 2414, Dec 1992. ISSN 0109-2502.

$\mathrm{PIOCH}, \mathrm{T}$. et al. Interfacial micromorphology and tensile bond strength of dentin bonding systems after $\mathrm{NaOCl}$ treatment. J Adhes Dent, v. 1, n. 2, p. 135-42, Summer 1999. ISSN 1461-5185.

QING, P. et al. Effect of gamma irradiation on the wear behaviour of human tooth enamel. Sci Rep, v. 5, p. 11568, 2015. ISSN 2045-2322.

RAMOS, R. P. et al. Bonding of self-etching and total-etch systems to Er:YAG laserirradiated dentin. Tensile bond strength and scanning electron microscopy. Braz Dent J, v. 15 Spec No, p. Si9-20, 2004. ISSN 0103-6440.

RETIEF, D. H. et al. A laboratory evaluation of three etching solutions. Dent Mater, v. 2, n. 5, p. 202-6, Oct 1986. ISSN 0109-5641.

RETTIG, E. M.; D'SOUZA, G. Epidemiology of head and neck cancer. Surg Oncol Clin N Am, v. 24, n. 3, p. 379-96, Jul 2015. ISSN 1055-3207.

SANTIN, G. C. et al. Physical and adhesive properties of dental enamel after radiotherapy and bonding of metal and ceramic brackets. Am J Orthod Dentofacial Orthop, v. 148, n. 2, p. 283-92, Aug 2015. ISSN 0889-5406.

SCHRATTER-SEHN, A. U. et al. [The prevention of mucosal lesions during oropharyngeal irradiation with a dental-filling shield]. Strahlenther Onkol, v. 168, n. 1, p. 35-8, Jan 1992. ISSN 0179-7158.

SECRETAN, B. et al. A review of human carcinogens--Part E: tobacco, areca nut, alcohol, coal smoke, and salted fish. Lancet Oncol, v. 10, n. 11, p. 1033-4, Nov 2009. ISSN 14702045.

SILVA, A. R. et al. Patterns of demineralization and dentin reactions in radiation-related caries. Caries Res, v. 43, n. 1, p. 43-9, 2009. ISSN 0008-6568.

SMITH, E. M. et al. Age, sexual behavior and human papillomavirus infection in oral cavity and oropharyngeal cancers. Int J Cancer, v. 108, n. 5, p. 766-72, Feb 20 2004. ISSN 00207136.

SOARES, C. J. et al. Effect of gamma irradiation on ultimate tensile strength of enamel and dentin. J Dent Res, v. 89, n. 2, p. 159-64, Feb 2010. ISSN 0022-0345.

Effects of chlorhexidine and fluoride on irradiated enamel and dentin. J Dent Res, v. $\overline{90, \text { n. } 5}$, p. 659-64, May 2011. ISSN 0022-0345. 
SPEARS, I. R. A three-dimensional finite element model of prismatic enamel: a re-appraisal of the data on the Young's modulus of enamel. J Dent Res, v. 76, n. 10, p. 1690-7, Oct 1997. ISSN 0022-0345.

SPRINGER, I. N. et al. Radiation caries--radiogenic destruction of dental collagen. Oral Oncol, v. 41, n. 7, p. 723-8, Aug 2005. ISSN 1368-8375.

TAY, F. R.; PASHLEY, D. H. Aggressiveness of contemporary self-etching systems. I: Depth of penetration beyond dentin smear layers. Dent Mater, v. 17, n. 4, p. 296-308, Jul 2001. ISSN 0109-5641.

TOTA, J. E. et al. Epidemiology and burden of HPV infection and related diseases: implications for prevention strategies. Prev Med, v. 53 Suppl 1, p. S12-21, Oct 2011. ISSN 0091-7435.

VAN LANDUYT, K. L. et al. Filler debonding \& subhybrid-layer failures in self-etch adhesives. J Dent Res, v. 89, n. 10, p. 1045-50, Oct 2010. ISSN 0022-0345.

Bond strength of a mild self-etch adhesive with and without prior acid-etching. $\mathbf{J}$ Dent, v. 34, n. 1, p. 77-85, Jan 2006. ISSN 0300-5712.

Are one-step adhesives easier to use and better performing? Multifactorial assessment of contemporary one-step self-etching adhesives. J Adhes Dent, v. 11, n. 3, p. 175-90, Jun 2009. ISSN 1461-5185.

VAN MEERBEEK, B. et al. Buonocore memorial lecture. Adhesion to enamel and dentin: current status and future challenges. Oper Dent, v. 28, n. 3, p. 215-35, May-Jun 2003. ISSN 0361-7734.

VISSINK, A. et al. Prevention and treatment of the consequences of head and neck radiotherapy. Crit Rev Oral Biol Med, v. 14, n. 3, p. 213-25, 2003. ISSN 1045-4411.

WALKER, M. P. et al. Impact of Radiotherapy Dose on Dentition Breakdown in Head and Neck Cancer Patients. Pract Radiat Oncol, v. 1, n. 3, p. 142-148, 2011.

WHITE, S. N. et al. Biological organization of hydroxyapatite crystallites into a fibrous continuum toughens and controls anisotropy in human enamel. J Dent Res, v. 80, n. 1, p. 321-6, Jan 2001. ISSN 0022-0345.

YOSHIDA, Y. et al. Comparative study on adhesive performance of functional monomers. $\mathbf{J}$ Dent Res, v. 83, n. 6, p. 454-8, Jun 2004. ISSN 0022-0345.

YOUNG, D. et al. Increase in head and neck cancer in younger patients due to human papillomavirus (HPV). Oral Oncol, v. 51, n. 8, p. 727-30, Aug 2015. ISSN 1368-8375.

ZHOU, J. et al. Smokeless tobacco and risk of head and neck cancer: evidence from a case-control study in New England. Int J Cancer, v. 132, n. 8, p. 1911-7, Apr 15 2013. ISSN 0020-7136. 
Anexo 

ANEXO 1

\section{FACULDADE DE ODONTOLOGIA DE RIBEIRÃO PRETO/ FORP/ USP}

\section{PARECER CONSUBSTANCIADO DO CEP}

\section{DADOS DO PROJETO DE PESQUISA}

Título da Pesquisa: INFLUÊNCIA DA RADIOTERAPIA NA RESISTÊNCIA ADESIVA AO ESMALTE E DENTINA DE DENTES PERMANENTES

Pesquisador: Juliana Arid

Área Temática:

Versão: 3

CAAE: 25258613.0 .0000 .5419

Instituição Proponente: Universidade de Sao Paulo

Patrocinador Principal: Financiamento Próprio

\section{DADOS DO PARECER}

Número do Parecer: 570.705

Data da Relatoria: 24/03/2014

\section{Apresentação do Projeto:}

A radioterapia, quando aplicada na região de cabeça e pescoço, pode ocasionar alterações estruturais na esmalte e na dentina, que podem ter parte na patogênese da cárie de radiação. Questiona-se então se essas alterações estruturais poderiam influenciar o comportamento dos diversos materiais restauradores, quando empregados em pacientes submetidos à radioterapia de cabeça e pescoço.

\section{Objetivo da Pesquisa:}

O objetivo deste trabalho será avaliar in vitro os efeitos da radiação sobre a resistência ao cisalhamento de restaurações de resina composta, empregando-se dois sistemas adesivos diferentes, em esmalte e dentina de dentes permanentes realizado antes e após tratamento com radiação. A amostra será constituída de 60 terceiros molares permanentes de humanos, superiores e inferiores, recém extraídos e hígidos, obtidos junto ao Banco de Dentes da Faculdade de Odontologia de Ribeirão Preto da Universidade de São Paulo.

\section{Avaliação dos Riscos e Benefícios:}

O trabalho é com dentes - estudo in vitro - não existem riscos previsíveis para participantes da pesquisa.

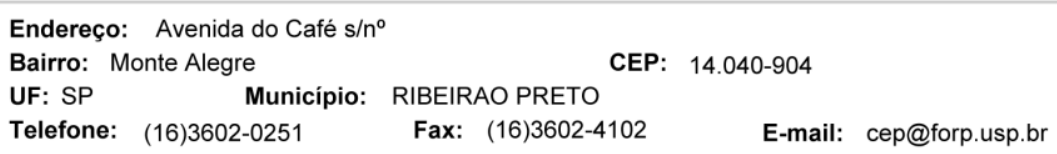




\section{FACULDADE DE ODONTOLOGIA DE RIBEIRÃO PRETO/ FORP/ USP}

Continuação do Parecer: 570.705

\section{Comentários e Considerações sobre a Pesquisa:}

O projeto é bem fundamentado, explícito e claro. Apresenta uma introdução referenciada, um material e método descritivo com todas as etapas do projeto que será executado em dentes humanos doados pelo Banco de Dentes da FORP. É um estudo in vitro, relevante para a área da Odontologia. Os pesquisadores são plenamente capacitados para o desenvolvimento do projeto. Inclui cronograma e análise estatística, assim como previsão de custos.

\section{Considerações sobre os Termos de apresentação obrigatória:}

O documento do Biobanco de Dentes está correto e a metodologia "Metodologia proposta" do projeto da Plataforma Brasil foi corrigida e está de acordo com a metodologia proposta no projeto de pesquisa.

\section{Recomendações:}

Não há.

\section{Conclusões ou Pendências e Lista de Inadequações:}

Protocolo aprovado. Os relatórios (parciais/final) deverão ser encaminhados, utilizando-se da opção ¿Enviar Notificação ¿ (descrita no Manual ¿Submeter Notificação ¿, disponível na Central de Suporte ¿ canto superior direito do portal www.saude.gov.br/plataformabrasil).

\section{Situação do Parecer:}

Aprovado

\section{Necessita Apreciação da CONEP:}

Não

Considerações Finais a critério do CEP:

Conforme deliberado na $161^{\text {a }}$ R.O. do CEP.

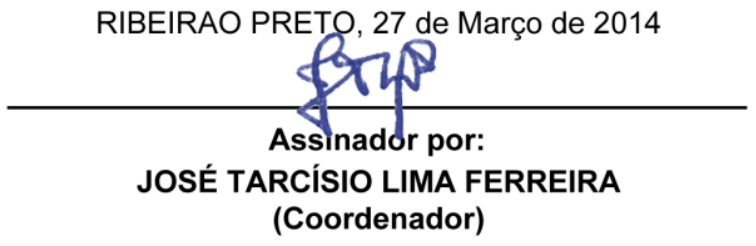

Endereço: Avenida do Café $s / n^{\circ}$

Bairro: Monte Alegre

UF: SP

Município: RIBEIRAO PRETO

Telefone: (16)3602-0251

Fax: (16)3602-4102

E-mail: cep@forp.usp.br 